\title{
Discoidin domain receptor 1 (DDR1) ablation promotes tissue fibrosis and hypoxia to induce aggressive basal-like breast cancers
}

\author{
Ken Takai, ${ }^{1,2}$ Allison P. Drain, ${ }^{3}$ Devon A. Lawson, ${ }^{1,6}$ Laurie E. Littlepage, ${ }^{1,7}$ Marcela Karpuj, ${ }^{1,8}$ \\ Kai Kessenbrock, ${ }^{1,9}$ Annie Le, ${ }^{1}$ Kenichi Inoue, $^{2}$ Valerie M. Weaver, ${ }^{3,4,5}$ and Zena Werb ${ }^{1}$ \\ ${ }^{1}$ Department of Anatomy, University of California at San Francisco, San Francisco, California 94143, USA; ${ }^{2}$ Division of Breast \\ Oncology, Saitama Cancer Center, Saitama 362-0806, Japan; ${ }^{3}$ Department of Surgery, Center for Bioengineering and Tissue \\ Regeneration, University of California at San Francisco, San Francisco, California 94143, USA; ${ }^{4}$ Department of Bioengineering and \\ Therapeutic Sciences, University of California at San Francisco, San Francisco, California 94143, USA; ${ }^{5}$ Department of Radiation \\ Oncology, University of California at San Francisco, San Francisco, California 94143, USA
}

The discoidin domain receptor 1 (DDR1) is overexpressed in breast carcinoma cells. Low DDR1 expression is associated with worse relapse-free survival, reflecting its controversial role in cancer progression. We detected DDR1 on luminal cells but not on myoepithelial cells of DDR1 ${ }^{+/+}$mice. We found that DDR1 loss compromises cell adhesion, consistent with data that older DDR1 ${ }^{-/}$mammary glands had more basal/myoepithelial cells. Basal cells isolated from older mice exerted higher traction forces than the luminal cells, in agreement with increased mammary branches observed in older DDR1 ${ }^{-/-}$mice and higher branching by their isolated organoids. When we crossed DDR1 ${ }^{-/-}$mice with MMTV-PyMT mice, the PyMT/DDR1 ${ }^{-/}$mammary tumors grew faster and had increased epithelial tension and matricellular fibrosis with a more basal phenotype and increased lung metastases. DDR1 deletion induced basal differentiation of $\mathrm{CD}^{+} \mathrm{CD}^{+} 4^{+}$cancer cells, and the increase in basal cells correlated with tumor cell mitoses. $\mathrm{K14}^{+}$basal cells, including $\mathrm{K}^{+} \mathrm{K}^{+} 4^{+}$cells, were increased adjacent to necrotic fields. These data suggest that the absence of DDR1 provides a growth and adhesion advantage that favors the expansion of basal cells, potentiates fibrosis, and enhances necrosis/hypoxia and basal differentiation of transformed cells to increase their aggression and metastatic potential.

[Keywords: DDR1; mammary development; breast cancer; necrosis/hypoxia; basal-like phenotype]

Supplemental material is available for this article.

Received May 2, 2017; revised version accepted January 24, 2018.

Discoidin domain receptor 1 (DDR1) is a member of the subfamily of receptor tyrosine kinases (RTKs) activated by collagen (Shrivastava et al. 1997; Vogel et al. 1997) and is widely expressed in human and mouse epithelial cells (Alves et al. 1995). In mice, the absence of DDR1 results in a delay of pubertal mammary ductal growth at 3 wk of age (Vogel et al. 2001). However, by 3 mo, the mammary glands of $D D R 1^{-/-}$mice show high collagen deposits in stroma, high proliferation rates of mammary epithelial cells, and increased mammary branches (Vogel et al. 2001). In part, these divergent roles of DDR1 in

Present addresses: ${ }^{6}$ Department of Physiology and Biophysics, Chao Family Comprehensive Cancer Center, University of California Irvine, Irvine, CA 92697, USA; ${ }^{7}$ Harper Cancer Research Institute, Department of Chemistry and Biochemistry, University of Notre Dame, South Bend, IN 46617, USA; ${ }^{8}$ Faculty of Medicine, Bar-Ilan University, Henrietta Sold 8, Safed, Israel; ${ }^{9}$ Department of Biological Chemistry, University of California Irvine, Irvine, CA 92697, USA.

Corresponding author: zena.werb@ucsf.edu

Article published online ahead of print. Article and publication date are online at http://www.genesdev.org/cgi/doi/10.1101/gad.301366.117. mammary development may be explained by the previous reports showing that in in vitro studies, DDR1 promotes cell proliferation, differentiation, and migration by degrading collagen (Hou et al. 2001; Ferri et al. 2004; Neuhaus et al. 2011; Roberts et al. 2011; Yeh et al. 2011). However, the possible mechanism of mammary hyperproliferation and hyperbranching by DDR1 ablation at later stages remains obscure.

Since events during development may be mirrored by events during tumor progression, understanding these roles for DDR1 in development may give insights into DDR1's roles in cancer. Nevertheless, the results of mammary development in $D D R 1^{-/-}$mice make it difficult to hypothesize whether DDR1 will promote or suppress

(C) 2018 Takai et al. This article is distributed exclusively by Cold Spring Harbor Laboratory Press for the first six months after the full-issue publication date (see http://genesdev.cshlp.org/site/misc/terms.xhtml). After six months, it is available under a Creative Commons License (Attribution-NonCommercial 4.0 International), as described at http://creativecommons.org/licenses/by-nc/4.0/. 
cancer. Indeed, DDR1 is associated with cancer. In several studies, the effects of DDR 1 in cancer progression suggest that it may be both procancer and anti-cancer, in keeping with the dual phenotypes in mammary development. DDR1 is overexpressed in breast, ovarian, and lung carcinoma cell lines (Johnson et al. 1993; Zerlin et al. 1993; Laval et al. 1994; Alves et al. 1995; Barker et al. 1995; Perez et al. 1996; Ford et al. 2007), and high expression of DDR1 correlates with poor prognosis of serous ovarian cancer, lung cancer, and pancreatic ductal adenocarcinoma (Quan et al. 2011; Valencia et al. 2012; Huo et al. 2015). On the one hand, activation of DDR1 by collagen promotes protumorigenic phenotypes, including up-regulation of the expression of MMP-1, MMP-2, and MMP-9; increased degradation of collagen; up-regulation of expression of SOX2 and NANOG; promotion of cell invasion; metastasis; and regulation of cancer stem cell traits (Hou et al. 2001, 2002; Ferri et al. 2004; Gao et al. 2016). DDR1 stabilizes E-cadherin (Eswaramoorthy et al. 2010; Yeh et al. 2011) and mediates suppression of actomyosin at cell-cell contacts to promote collective cell migration (Hidalgo-Carcedo et al. 2011). Interference with DDR1 signaling in metastatic breast cancer cell lines decreases their ability to colonize lung tissue (Hidalgo-Carcedo et al. 2011; Gao et al. 2016). Moreover, knockdown of DDR1 decreases the viability of breast, pancreatic, and ovarian cancer cell lines (Marcotte et al. 2012). These studies indicate that DDR1 might function as an oncogene.

On the other hand, a moderate reduction in DDR1 mRNA levels was shown in the majority of middle- to high-grade human breast carcinomas compared with normal mammary tissues (Neuhaus et al. 2011). Another clinical study of lung cancer patients showed that low expression of DDR1 is associated with a worse prognosis than its high expression (Ford et al. 2007). Also, a clinical study of breast cancer patients showed that DDR1 expression was not predictive for survival (Ren et al. 2013). Furthermore, induction of DDR1 may inhibit migration of a DDR1-deficient breast cancer cell line (Hansen et al. 2006). Disruption of DDR1 in cell-cell contacts in cancer may favor metastasis by invading blood vessels (HidalgoCarcedo et al. 2011). These data indicate that deletion of DDR1 might promote aggressive cancer. As a result, the role of DDR1 in cancers is controversial.

To understand the role of DDR1 in breast tumorigenesis, we established an animal model using DDR1 knockout mice crossed into the MMTV-PyMT mouse and tested the hypothesis that DDR1 ablation leads to an aggressive form of breast cancer. We then analyzed breast cancer databases to establish how DDR1 levels are related to prognosis.

\section{Results}

DDR1 is expressed in luminal epithelial cells and regulates basal/myoepithelial cells

Since the effects of genes in development may give insights into their roles in cancer, we first verified the role of DDR1 in normal mammary gland development using the DDR $1^{-/-}$mouse model. When we analyzed the mammary gland tissues from DDR $1^{+/+}$mice by immunostaining with anti-DDR1 antibody and anti- $\alpha$-smooth muscle actin ( $\alpha$-SMA) antibody, which is a marker of myoepithelial cells, we detected DDR1 in the luminal cell compartment but not on myoepithelial cells (Fig. 1A), as was found in the kidneys, where DDR1 expression also does not colocalize with staining for a-SMA following kidney injury (Lee et al. 2004).

In whole-mount carmine red-stained mammary gland tissues in $\mathrm{DDR}^{+/+}$and DDR $1^{-/-}$mice, we observed two distinct phenotypes: one during active pubertal growth and another in adult mammary glands. Mammary development, as assayed by primary duct lengths and frequency of mammary duct branches, was delayed in 5-wk-old DDR $1^{-/-}$mice but accelerated in 8-wk-old DDR $1^{-/-}$ mice (Fig. 1B,C). Our results showing distinct stage-specific effects of DDR1 (Table 1) are consistent with a previous analysis showing that development of mammary glands was delayed in 3-wk-old DDR $1^{-/-}$mice but that the number of mammary ducts was increased in 12-wk-old $\mathrm{DDR}^{-/-}$mice due to hyperproliferation of the epithelium (Vogel et al. 2001).

To determine the mechanisms that might be involved in the altered branching phenotype, we generated a cell line with a DDR1 knockdown. Consistent with the literature, the DDR1 knockdown mammary epithelial cells were slower in attaching to collagen than the wild-type control (Supplemental Fig. S1A; Ram et al. 2006; Xu et al. 2012). In keeping with this phenotype, the DDR1 knockdown cells were less contractile when seeded within collagen gels (Supplemental Fig. S1B). These data along with the known role of DDR1 in supporting collective cell migration suggest that DDR1 knockout directly impairs the ability of the luminal population to properly organize and execute branching morphogenesis (Hidalgo-Carcedo et al. 2011). Indeed, by flow cytometry analysis, we observed that the basal/myoepithelial CD24 ${ }^{\text {low }}$ CD $49 f^{\text {high }}$ cell population was similar in $\mathrm{DDR} 1^{-/-}$and $\mathrm{DDR} 1^{+/+}$ mice in puberty at $5 \mathrm{wk}$ of age but was significantly increased in adult 8 -wk-old DDR $1^{-/-}$mouse mammary glands compared with DDR $1^{+/+}$mice (Fig. 1D,E).

Collagen contraction assays and traction force microscopic analysis of the basal versus the luminal isolated populations revealed that the basal cells are significantly more contractile (Fig. 1F). The relevance of the altered ratio of highly contractile basal cells to luminal cells was explored by coculturing aggregates of luminal and basal cells and assaying for branching morphogenesis. First, we crossed K14-GFP mice with the DDR1 knockout mouse line. We then isolated $\mathrm{K} 14^{-}$luminal cells and $\mathrm{K} 14^{+}$ basal/myoepithelial cells from $\mathrm{K} 14^{+} / \mathrm{DDR} 1^{+/+}$mouse mammary glands by flow cytometry (Supplemental Fig. $\mathrm{S} 1 \mathrm{C})$, aggregated the $\mathrm{K} 14^{-}$luminal cells with and without $\mathrm{K}_{14}{ }^{+}$highly contractile basal cells overnight, collected the cell aggregates, and cultured them in Matrigel for three-dimensional (3D) organoid branching assays. Aggregating $\mathrm{K} 14^{-}$luminal cells with $\mathrm{K} 14^{+}$contractile basal/myoepithelial cells promoted mammary branching (Supplemental Fig. S1D). We then isolated K14- luminal cells and 
A

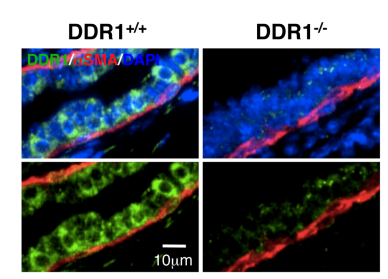

C

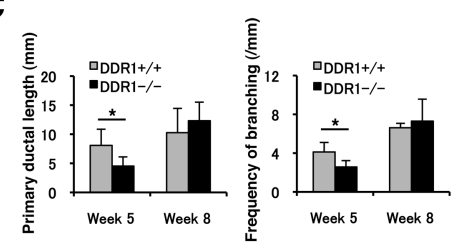

E

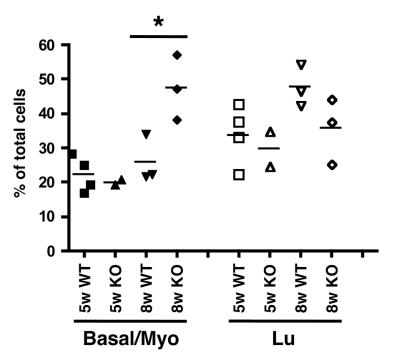

B

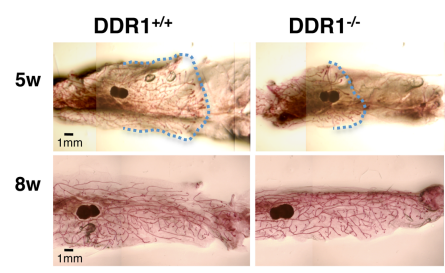

D

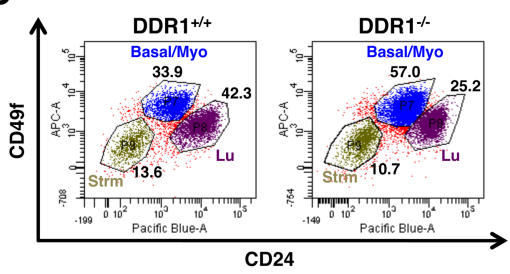

$\mathbf{F}$

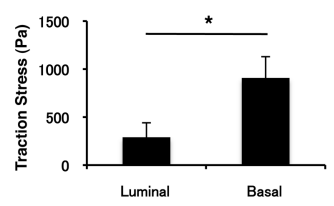

G

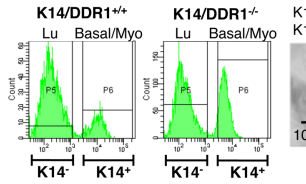

H
$\mathrm{K} 14^{+/ D D R 1^{1++}} \mathrm{B}$ cells $\mathrm{K} 14^{+/ D D R 1^{-/}} \mathrm{B}$ cells $\mathrm{K} 14^{+/ D D R 1^{++}} \mathrm{B}$ cells

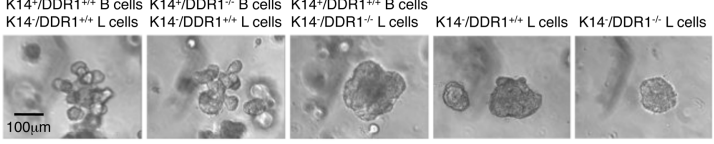

Figure 1. DDR1 is expressed in luminal epithelial cells and regulates basal/myoepithelial cells. $(A) \mathrm{Im}$ munofluorescence of mammary glands from DDR1 ${ }^{-/-}$mice was conducted by using anti-DDR 1 (green) and anti- $\alpha$-SMA (red) antibodies. DDR1 was detected in the luminal cell compartment but not on myoepithelial cells. $(B, C)$ Carmine red wholemount staining of representative mammary glands showed that mammary development of DDR1 ${ }^{-/-}$ mice was delayed at $5 \mathrm{wk}$ but promoted at $8 \mathrm{wk}$. $(B)$ The mammary ducts reached the dashed lines at 5 wk. $(C)$ Primary ductal length (in millimeters) (left panel) and frequency of mammary branching (branches per millimeter) (right panel) are shown. Data are shown as mean \pm SD. $n=3-4 .\left(^{*}\right) P<0.05$, unpaired Student's $t$-test. $(D, E)$ Flow cytometry analysis was conducted using anti-CD24 and anti-CD49f antibodies to examine the relationship between mammary development and epithelial populations. $(D)$ Representative data are shown. (Basal/Myo) Basal/myoepithelial cells; (Lu) luminal cells; (Strm) stromal cells. (E) Basal/myoepithelial (CD24 ${ }^{\text {low }}$ CD49f figh) cells increased in 8-wk-old DDR $1^{-/-}$mammary glands. (*) $P$ $<0.05$, one-way ANOVA and unpaired Student's $t$ test. $(F)$ Traction stresses generated on collagen-coated polyacrylamide gels by luminal (CD24 $4^{\text {high }}$ CD49flow) and basal/myoepithelial (CD24 $4^{\text {low }}$ CD49h high cells isolated from wild-type murine mammary glands by flow cytometry. The results shown represent the maximum traction stress generated by single cells. (*) $P<0.01$, unpaired Student's $t$ test. $(G, H) \mathrm{K} 14^{-}$luminal cells and $\mathrm{K} 14^{+}$basal/myoepithelial cells were isolated from $\mathrm{K} 14 / \mathrm{DDR} 1^{+/+}$mice and $\mathrm{K} 14 / \mathrm{DDR}^{-/-}$mice by flow cytometry (shown

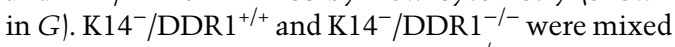
and aggregated with $\mathrm{K}_{1} 4^{+} / \mathrm{DDR}^{+/+}$and $\mathrm{K}_{1} 4^{+} /$ $\mathrm{DDR} 1^{-/-}$for a three-dimensional (3D) branching as-

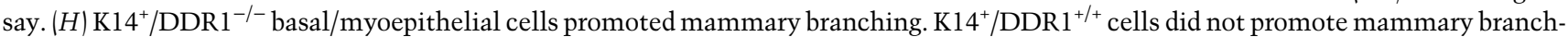
ing of $\mathrm{K}_{1} 4^{-} / \mathrm{DDR} 1^{-/-}$luminal cells.

$\mathrm{K} 14^{+}$basal/myoepithelial cells from $\mathrm{K} 14 / \mathrm{DDR} 1^{+/+}$mice and $\mathrm{K} 14 / \mathrm{DDR} 1^{-/-}$mice by flow cytometry and aggregated

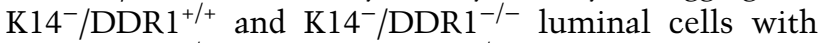
$\mathrm{K}_{1} 4^{+} / \mathrm{DDR} 1^{+/+}$and $\mathrm{K} 14^{+} / \mathrm{DDR}^{-/-}$basal cells (Fig. 1G). $\mathrm{K} 14^{+} / \mathrm{DDR} 1^{-/-}$contractile basal/myoepithelial cells promoted mammary branching (Fig. 1H). Since DDR1 is not expressed on myoepithelial cells and since incubation of $\mathrm{K} 14^{-} / \mathrm{DDR} 1^{-/-}$luminal cells with $\mathrm{K} 14^{+} / \mathrm{DDR} 1^{+/+}$basal/ myoepithelial cells did not promote mammary branching (Fig. 1H), this result indicates that DDR1 on luminal cells

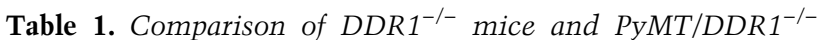
mice

\begin{tabular}{|c|c|}
\hline $\mathrm{DDR} 1^{-/-}$ & PyMT/DDR $1^{-/-}$ \\
\hline Branching $\downarrow$ (in vitro) & Branching $\downarrow$ (in vitro) \\
\hline $\begin{array}{l}\text { Branching } \downarrow \text {, duct length } \downarrow \text { ( } 5 \text { wk in } \\
\text { vivo) }\end{array}$ & Small clusters (in vivo) \\
\hline Branching $\uparrow$ (8 wk in vivo) & $\begin{array}{l}\text { Tumor growth } \uparrow \text { (in } \\
\text { vivo) }\end{array}$ \\
\hline $\begin{array}{l}\text { Basal/myoepithelial cells } \uparrow \text { ( } 8 \text { wk in } \\
\text { vivo) }\end{array}$ & $\mathrm{K} 14^{+}$cells $\uparrow$ (in vivo) \\
\hline
\end{tabular}

and interaction with $\mathrm{K} 14^{+}$contractile basal/myoepithelial cells are required for mammary branching, likely mediated through a combination of tension-mediated interactions and paracrine signaling.

These data suggest stage-specific roles for DDR1 during mammary development. Thus, reduction of mammary branching at $5 \mathrm{wk}$ of age in $\mathrm{DDR}^{-/-}$mice may be due to the loss of DDR1 functions as a collagen receptor and collective cell migration in luminal cells, whereas the accelerated branching in $\mathrm{DDR}^{-/-}$mice at 8 wk of age may be the result of the expansion of the basal/myoepithelial compartment.

\section{DDR $1^{-/-}$mammary tumors grow faster and are more basal and necrotic}

To determine how DDR 1 alters in breast tumor prognosis, we determined whether deletion of DDR1 leads to more aggressive breast tumors. We crossed $\mathrm{DDR} 1^{-/-}$mice with MMTV-PyMT mice, a transgenic luminal B breast cancer model (Supplemental Fig. S2A; Lin et al. 2003). We validated DDR1 expression levels in primary tumors 
of PyMT/DDR $1^{+/+}$, PyMT/DDR1 ${ }^{+/-}$, and PyMT/DDR1 $1^{-/-}$ mice by quantitative PCR (qPCR). As expected, PyMT/ DDR $1^{-1-}$ mice did not express DDR 1 , whereas DDR 1 expression in PyMT/DDR1 $1^{+/}$was intermediate as compared with PyMT/DDR1 ${ }^{+/+}$(Supplemental Fig. S2B).

In support of this model, we found that DDR1 expression was higher in luminal-type than basal-type human cancer cells (Supplemental Fig. S2C; Neve et al. 2006).

Tumors from both PyMT/DDR $1^{+/-}$and PyMT/DDR $1^{+/+}$ mice had similar growth rates (Fig. 2A). In contrast, primary tumors of PyMT/DDR1 ${ }^{-/-}$mice grew faster (although there were no differences in the tumor onset) (Fig. 2A; Supplemental Fig. S3A) and often showed necrotic areas with hemorrhage (Supplemental Fig. S3B). In hematoxylin and eosin (H\&E)-stained tissue sections, the tumor tissues had large necrotic regions with more differentiated epithelial clusters surrounding the necrotic regions. The $\mathrm{DDR}^{+/+}$and $\mathrm{DDR}^{+/-}$mammary tumors were largely made up of large epithelial glandular clusters, while the DDR $1^{-7-}$ mammary tumors had small areas of differentiated epithelial clusters with increased areas of necrosis (Fig. 2B-D). Even small clusters had necrotic areas in the DDR $1^{-1-}$ mammary tumors (Supplemental Fig. S3C).

We next determined whether the proliferative status of these tumors was related to their growth rates by staining tissues for phospho-histone $\mathrm{H} 3$ ( $\mathrm{phH} 3$ ). $\mathrm{PhH}^{+}$cells were localized in the tumors mainly around the edges of the epithelial clusters. PyMT/DDR $1^{-/-}$mammary tumors had significantly more $\mathrm{phH} 3^{+}$cells than control tumors that expressed DDR1 (Fig. 2E,F). This suggests that DDR1 $1^{-/}$ mammary tumors are more proliferative than $\mathrm{DDR} 1^{+/+}$.

We also examined expression of luminal markers (E-cadherin and keratin 8 [K8]) and basal markers (keratin 14 [K14], vimentin, and DDR2) in primary tumors by immunofluorescence. Vimentin expression levels increased in DDR $1^{-/-}$epithelial clusters (Fig. $2 \mathrm{G}, \mathrm{H}$ ). $\mathrm{K} 14^{+}$basal cells mainly encircled the edges of the epithelial clusters in all three genotypes (Fig. 2I). However, $\mathrm{K}^{+} 4^{+}$basal cells in DDR $1^{-1-}$ tumor epithelial clusters increased in numbers, while the expression levels of E-cadherin in DDR1 ${ }^{-/-}$epithelial clusters decreased (Fig. 2I,J).

Since DDR2 also affects tumor progression (Zhang et al. 2013; Corsa et al. 2016), we asked whether its expression was changed in the absence of DDR1. We observed that $\mathrm{DDR}^{+}$cells increased in numbers in DDR $1^{-/-}$epithelial clusters and near the necrotic area (Fig. 2K,L; Supplemental Fig. S3D,E).

We also observed a trend toward increased $\mathrm{K} 8{ }^{+} \mathrm{K} 14^{+}$ basal-like cells in DDR1 ${ }^{-/-}$epithelial clusters (Supplemental Fig. S3F,G). However, more $\mathrm{K}^{+} \mathrm{K}_{14} 4^{+}$basal-like cells were seen in the epithelial regions at the outer edge of the necrosis (Supplemental Fig. S3H,I). K14+ basal cells $\left(\mathrm{K} 8^{+} \mathrm{K} 14^{+}\right.$and $\mathrm{K} 8^{-} \mathrm{K} 14^{+}$cells) significantly increased in $\mathrm{DDR}^{-/-}$epithelial regions next to necrosis (Fig. 2M,N), while $\mathrm{K} 8^{+} \mathrm{K} 14^{+}$basal-like cells tended to increase (Supplemental Fig. S3J).

We then determined which cell compartment proliferated in DDR $1^{-1-}$ mammary tumors by staining tissues for $\mathrm{K} 8, \mathrm{~K} 14$, and phH3. $\mathrm{PhH}_{3}{ }^{+}$cells were localized mainly in $\mathrm{K}^{+}$luminal cells of the epithelial clusters (Supplemen- tal Fig. S4A,B). Moreover, $\mathrm{K} 8^{+} \mathrm{K} 14^{+}$basal-like cells proliferated at significantly higher rates, especially near the necrotic regions in DDR $1^{-/-}$mammary tumors (Supplemental Fig. S4C,D). $\mathrm{PhH} 3$ positivity correlated with $\mathrm{K} 14^{+}$basal cell numbers (correlation coefficient $r=0.75$ ) rather than $\mathrm{K} 8{ }^{+} \mathrm{K} 14^{+}$basal-like cell numbers $(r=0.07)$ in epithelial clusters.

Finally, to examine whether DDR1 deletion alters the phenotype of $\mathrm{K}^{+} \mathrm{K}_{14}{ }^{+}$basal-like cells, we stained tumor tissues for K8, K14, and DDR2. $\mathrm{K}^{+} \mathrm{K} 14^{+}$basal-like cells, which up-regulated DDR2 expression, increased significantly in DDR1 $1^{-/-}$mammary tumors (Supplemental Fig. S5A,B). Moreover, DDR1 deletion decreased branching in tumor organoids in vitro (Supplemental Fig. S5C,D).

These data suggest that tumor growth correlates with $\mathrm{K} 14^{+}$basal cell numbers and that when DDR 1 is knocked out, the tumors have a more basal phenotype and are more aggressive. Taken together, these data suggest that loss of DDR1 may lead to breast cancers of poorer prognosis.

\section{Hypoxic regions show increased hypoxia-inducible factor-1 $\alpha$ (HIF1 $\alpha$ ) expression}

Tumor necrosis is significantly associated with hypoxia and in basal-type breast cancer and is an independent predictor for early recurrence and death (Gilchrist et al. 1993; Fulford et al. 2006). Since reduced expression of DDR1 in primary tumors increased the amount of necrosis in tumors (Fig. 2D), we hypothesized that necrosis and hypoxia might be linked in the DDR $1^{-/-}$tumors. Using immunofluorescent staining for HIFla in primary tumors, we observed that tumor necrosis was associated with hypoxia. HIFla was highly increased in the PyMT/DDR $1^{-/-}$mammary tumor tissue and was expressed near necrotic regions (Fig. 2O).

\section{PyMT/DDR $1^{-/-}$tumors have increased fibrosis and exhibit increased mechanochemical tension}

Basal-like breast tumors often present as highly fibrotic, which contributes to disease aggression through enhanced tumor cell mechanosignaling and impaired vascularization, leading to hypoxia (Leight et al. 2017; Northey et al. 2017). Consistently, picrosirius red staining showed that the more basal-like DDR $1^{-/}$tumors contain significantly more fibrillar collagen than the DDR $1^{+/+}$tumors (Fig. 3A,B). Atomic force microscopy (AFM) further revealed that the $\mathrm{DDR} 1^{-/-}$tumors have a higher elastic modulus than the DDR $1^{+/+}$controls (Fig. 3C,D). To determine whether the stiffened collagen-rich extracellular matrix (ECM) of DDR1 ${ }^{-/-}$tumors corresponded to a higher level of mechanosignaling within the tumor, we analyzed levels of focal adhesion kinase (FAK) phosphorylation at Tyr397 in tumor lysates (Fig. 3E). We observed increased FAK phosphorylation in the DDR $1^{-/-}$tumors, which is indicative of integrin-mediated signaling and focal adhesion formation that has been shown to promote tumor progression (Levental et al. 2009). Moreover, the loss of DDR1 resulted in more contractile tumors, as shown by increased pMLC2 staining in the DDR $1^{-/-}$tumors (Fig. 3F,G). Given 
A

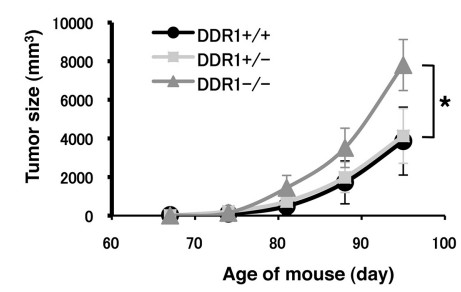

B

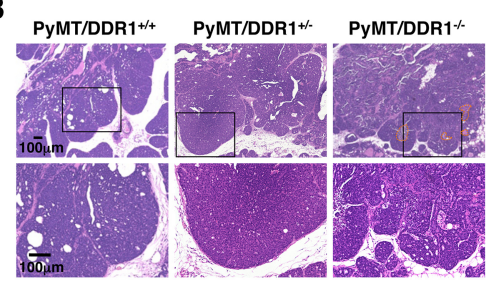

C

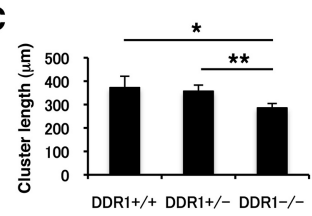

D

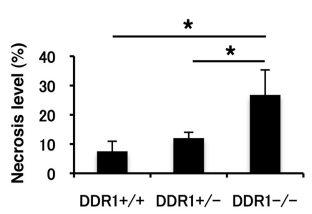

E

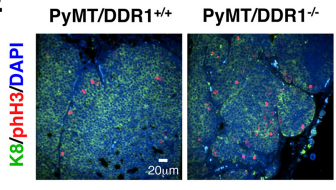

F

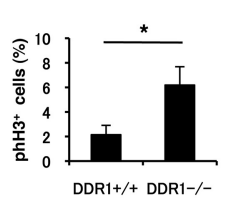

G

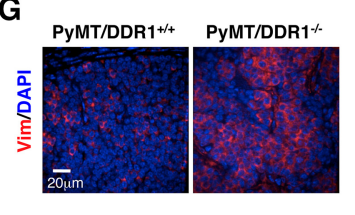

H

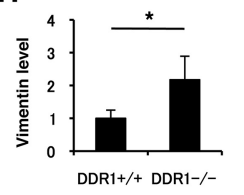

I

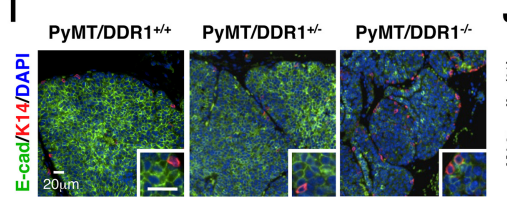

\section{J}
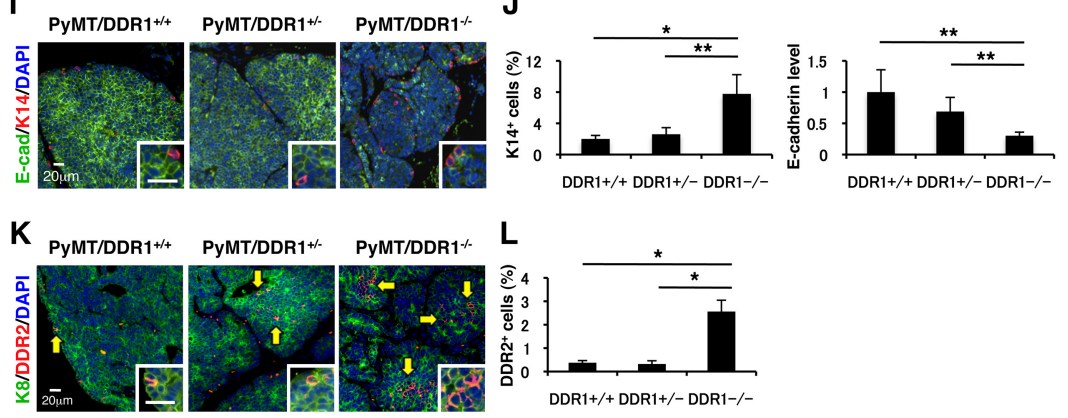

M

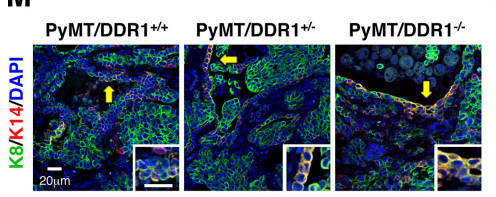

N

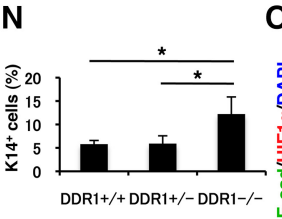

0

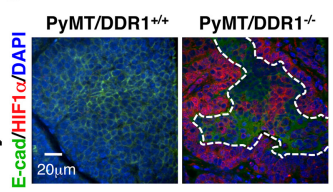

Figure 2. DDR $1^{-/-}$mammary tumors grow faster and are more basal and necrotic. $(A)$ Primary tumor burden of PyMT/DDR $1^{-/-}$mice compared with PyMT/DDR $1^{+/+}$and PyMT/ $\mathrm{DDR}^{+/-}$mice. PyMT/DDR $1^{-/-}$mammary tumors grow faster than control tumors. Data are shown as mean \pm SD. $n=4-7 .\left({ }^{*}\right) P<$ 0.02 , one-way ANOVA and unpaired Student's $t$-test. (B) DDR $1^{+/+}$and DDR $1^{+/-}$mammary tumors showed large epithelial clusters, and DDR $1^{-/-}$tumors showed multiple small clusters and central necrosis (orange dots) by $\mathrm{H} \& \mathrm{E}$ staining. Representative photographs are shown (13 wk). $n=3$. (C) The lengths of epithelial tumor clusters were measured. DDR $1^{-/-}$primary tumors show small clusters by H\&E staining. Data are shown as mean \pm SD. $n=3 .\left(^{*}\right) P<0.05$; $\left(^{* *}\right) P<0.02$, one-way ANOVA and unpaired Student's $t$-test. $(D)$ Percentage of necrotic clusters out of small clusters (200-300 $\mu \mathrm{m}$ in length) was measured. Necrotic small clusters increased in $\mathrm{DDR}^{-1-}$ tumors. Data are shown as mean \pm SD. $n=3 .\left({ }^{*}\right) P<0.02$, one-way ANOVA and unpaired Student's $t$-test. $(E, F)$ Immunofluorescence of $\mathrm{DDR} 1^{+/+}$and DDR $1^{-/-}$mammary tumor tissues using anti-keratin 8 (anit-K8) (green) and anti-phospho-histone $\mathrm{H} 3$ (phH3) (red) antibodies. (Blue) DAPI-stained nuclei. (E) Representative photographs are shown. $\mathrm{PhH}_{3}{ }^{+}$cells were present mainly at the edge of the epithelial clusters. $(F)$ The percentage of $\mathrm{phH}^{+}$cells per epithelial cell $\left(\mathrm{K}^{+}\right.$and phH $3^{+}$) shows that DDR $1^{-/}$mammary tumor cells are more proliferative. Data are shown as mean \pm SD. $n=3$. $\left(^{*}\right) P<0.02$, unpaired Student's $t$-test. $(G)$ Immunofluorescence of $\mathrm{DDR}^{+/+}$and DDR1 $1^{-/-}$mammary tumor tissues using anti-vimentin antibody (red) and DAPI-stained nuclei (blue). Representative photographs are shown. $(H)$ Expression levels of vimentin were quantified by using ImageJ software. Vimentin levels increased in DDR $1^{-/-}$epithelial clusters. Data are shown as mean \pm SD. $n=4 .\left(^{*}\right) P<0.05$, unpaired Student's $t$-test. $(I, J)$ Immunofluorescence of $\mathrm{DDR}^{+/+}, \mathrm{DDR}^{+/-}$, and DDR1 $1^{-/-}$mammary tumor tissues using anti-E-cadherin (green) and anti-keratin 14 (anti-K14) (red) antibodies and DAPI-stained nuclei (blue). (I) $\mathrm{K}_{1} 4^{+}$basal cells were mainly at the edges of the epithelial clusters. Representative photographs are shown. $(J)$ The ratio of $\mathrm{K}^{4} 4^{+}$basal cells per epithelial $\left(\mathrm{E}-\mathrm{cadherin}{ }^{+}\right.$and $\left.\mathrm{K} 14^{+}\right)$cell increased $\left(\left[^{*}\right] P<0.02\right.$; $\left[{ }^{* *}\right] P<0.05$, one-way ANOVA and unpaired Student's $t$-test) (left panel) and expression of E-cadherin decreased $([* *] P<0.05$, one-way ANOVA and unpaired Student's $t$-test) (right panel) in DDR $1^{-/}$epithelial clusters. Data are shown as mean \pm SD. $n=3$. $(K, L)$ Immunofluorescence of the primary tumors was performed by using anti-K8 (green) and anti-DDR2 (red) antibodies. (Blue) DAPI-stained nuclei. (K) Representative photos of tumor epithelial clusters are shown. $(L)$ The ratio of DDR2 ${ }^{+}$cells per epithelial cell increased significantly in DDR $1^{-/-}$epithelial clusters. Data are shown as mean \pm SD. $n=3$. $\left(^{*}\right) P<0.01$, one-way ANOVA and unpaired Student's $t$-test. $(M, N)$ Immunofluorescence of DDR $1^{+/+}$, $\mathrm{DDR}^{+/-}$, and DDR1 ${ }^{-/-}$mammary tumor tissues was conducted by using anti-K8 (green) and anti-K14 (red) antibodies. (Blue) DAPIstained nuclei. $(M)$ Representative photos of tumor necrotic areas are shown. $(N) \mathrm{K} 14^{+}$basal cells, including K8 ${ }^{+} \mathrm{K} 14^{+}$basal-like cells $(\mathrm{yel}-$ low), significantly increased near necrotic fields of DDR $1^{-/-}$mammary tumor tissues. Data are shown as mean \pm SD. $n=3$. $\left({ }^{*}\right) P<0.05$, oneway ANOVA and unpaired Student's $t$-test. (O) Immunofluorescence of DDR $1^{-/}$mammary tumor tissues using anti-E-cadherin (green) and anti-hypoxia-inducible factor a (anti-HIFla) (red) antibodies and DAPI-stained nuclei (blue). (Right panel) The white dots represent a border between an epithelial and a necrotic field. HIFla is expressed and localized near necrosis.

the reduction in cell contractility upon DDR1 knockdown in vitro, we asked whether the increased contractility in DDR1 ${ }^{-/-}$tumors could be attributed to the dramatic expansion of the basal/myoepithelial compartment in DDR $1^{-/-}$mammary glands. Indeed, using trac- tion force microscopy on flow-sorted luminal and basal/myoepithelial cells from the murine mammary glands, we also showed that the basal/myoepithelial cells generated much higher traction forces (Fig. 1F). These data suggest that the aggressive basal-like phenotype of 
A

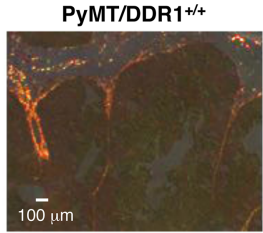

C

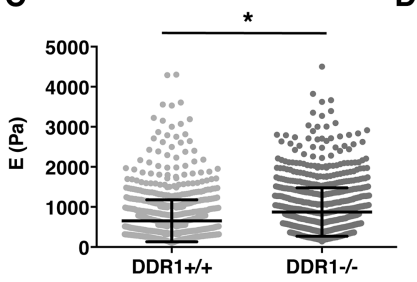

$\mathbf{F}$
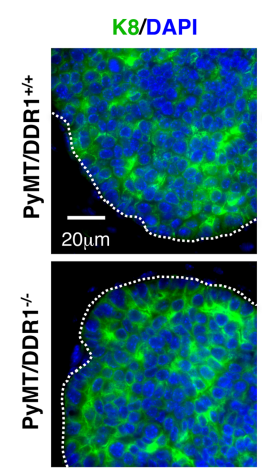

PyMT/DDR1 1

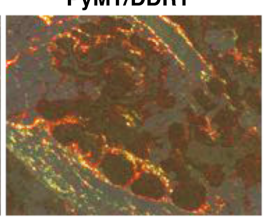

D
B

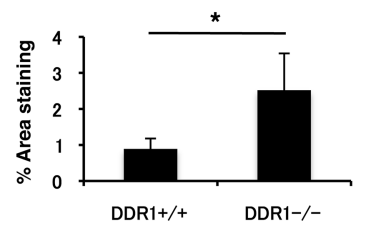

E

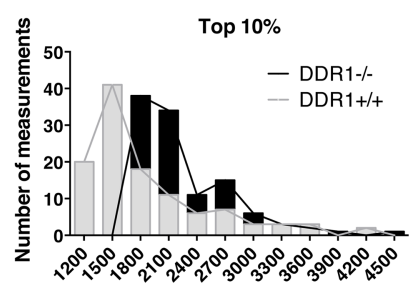

Elastic Modulus (Pa)
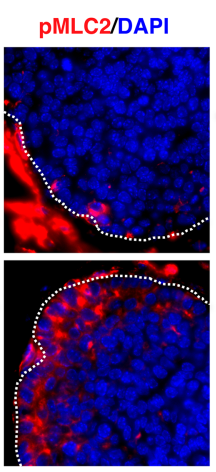

K8/pMLC2/DAPI

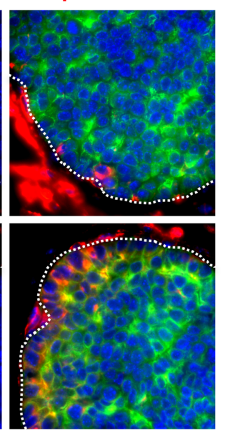

G
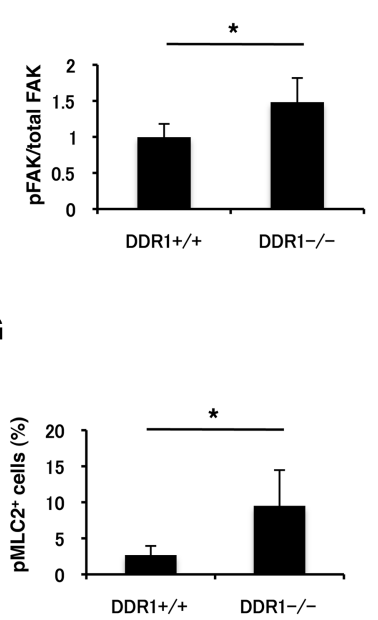

Figure 3. PyMT/DDR $1^{-/-}$tumors have increased fibrosis and exhibit increased mechanochemical tension. $(A, B)$ Picrosirius red staining of primary tumors $(A)$ and quantification $(B)$ by the percent area of birefringent signal in each image. $(A)$ Representative photographs are shown. $(B) \mathrm{DDR} 1^{-/-}$tumors contain significantly more fibrillar collagen than DDR $1^{+/+}$tumors. Data are shown as mean $\pm \mathrm{SD} . n=3 .\left({ }^{*}\right) P<$ 0.05 , unpaired Student's $t$-test. $(C, D)$ Quantification of tissue elastic modulus measured by AFM. $(C)\left({ }^{*}\right) P<0.0001, M a n n-W h i t n e y ~ U$-test. $(D)$ The histogram shows the distribution of the top $10 \%$ of measurements for each group. DDR $1^{-/-}$tumors have a higher elastic modulus than DDR1 $1^{++}$tumors. (E) Quantification of Western blots for $\mathrm{pFAK}^{\mathrm{Y} 397}$ protein in wild-type and DDR1 knockout tumor tissue lysates normalized to total FAK protein levels. FAK phosphorylation increased in DDR $1^{-1-}$ tumors. Data are shown as mean $\pm \mathrm{SD}$. $n=6$. $\left({ }^{*}\right) P$ $<0.02$, unpaired Student's $t$-test. $(F, G)$ Immunofluorescence of the primary tumors was performed by using anti-K8 (green) and antipMLC2 (red) antibodies. (Blue) DAPI-stained nuclei. $(F)$ Representative photographs are shown. The white dots represent a border between an epithelium and a stroma. $(G)$ The ratio of $\mathrm{pMLC} 2^{+}$cells per epithelial cell increased significantly in DDR $1^{-/-}$tumors. Data are shown as mean \pm SD. $n=3$. $\left(^{*}\right) P<0.05$, unpaired Student's $t$-test.

the DDR $1^{-/-}$tumors may result from a competitive advantage of the already enriched basal population due to a DDR1-dependent impairment in luminal cell interactions with the ECM.

\section{Loss of DDR1 results in increased lung metastases}

Since basal tumors with increased basal markers have a poor outcome in breast cancer patients (Perou et al. 2000; Sorlie et al. 2001, 2003; van de Rijn et al. 2002), we next determined whether DDR1 plays a role in lung metastasis. When we scored the macroscopic and microscopic metastatic burden, we found increased metastasis in both volume and numbers of metastases in the lungs of PyMT/DDR $1^{-/-}$mice (Fig. 4A-C). When we examined the epithelial differentiation state of metastatic tumors in the lungs, we found $\mathrm{K} 8^{+} \mathrm{K} 14^{+}$basal-like cells in most of the metastatic tumors even with any small size regardless of DDR1 genotype (Fig. 4D,E). Next, to examine whether DDR1 deletion is associated with the epithelial differentiation, we focused on the proportion of $\mathrm{K}^{-} \mathrm{K} 14^{+}$basal cells in the small metastatic tumors and found that $\mathrm{K}^{-} \mathrm{K} 14^{+}$basal cells significantly increased in DDR1 $1^{-/-}$metastases (Fig. 4F,G). These results suggest that DDR1 deletion might induce basal differentiation.

$C D 90^{+} C D 24^{+}$cells from PyMT/DDR $1^{-/-}$tumors transplanted into wild-type mice yield high-grade tumors resembling the PyMT/DDR $1^{-/-}$primary tumors

$\mathrm{CD} 90^{+} \mathrm{CD} 24^{+}$cells are enriched for metastasis-initiating cells (Malanchi et al. 2012). Based on the increased metastasis, we asked whether PyMT/DDR $1^{-/-}$tumors are enriched in $\mathrm{CD} 90^{+} \mathrm{CD} 24^{+}$cells and found that the DDR $1^{-/-}$mammary tumor cell populations contained 
A

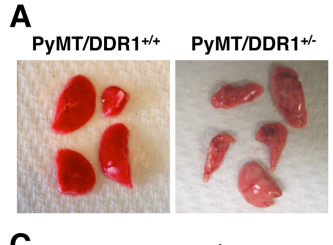

C

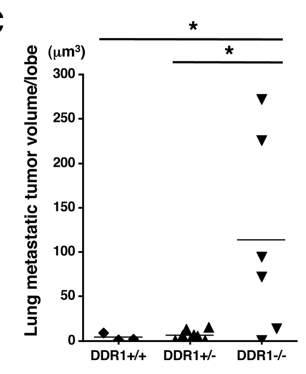

D

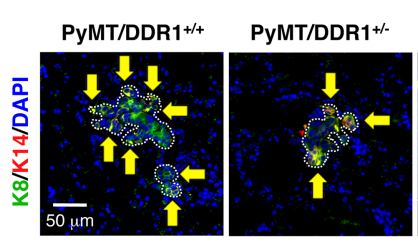

$\mathbf{F}$

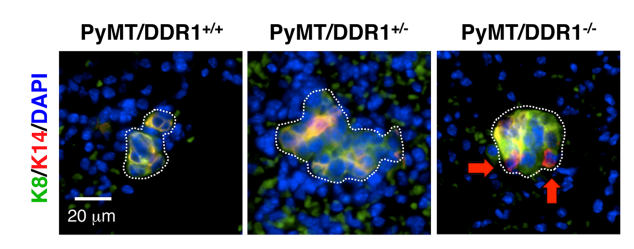

B

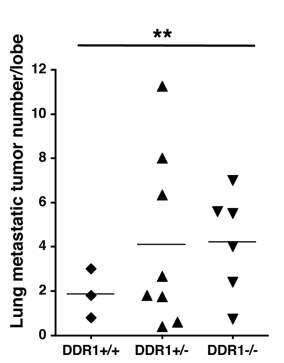

PyMT/DDR1 $\%$

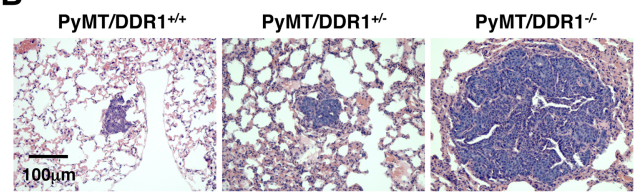

E

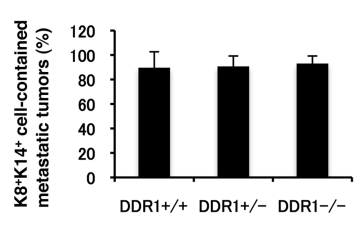

G

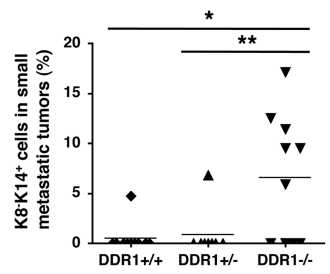

Figure 4. Loss of DDR1 results in increased lung metastases. (A) PyMT/ DDR $1^{-/-}$mice show larger and increased lung metastatic tumors macroscopically. (B) PyMT/DDR $1^{-/-}$mice have larger and increased numbers of lung metastatic tumors by H\&E staining. (C) The left panel indicates lung tumor volume. The right panel indicates lung tumor number per lobe. $\left({ }^{*}\right) P$ $<0.05$, one-way ANOVA and unpaired Student's $t$-test; $\left({ }^{* *}\right) P<0.05$, unpaired Student's $t$-test. $(D-G)$ Immunofluorescence of lungs using anti-K8 (green) and anti-K14 (red) antibodies and DAPI-stained nuclei (blue). Metastatic tumor cells are located inside the dashed lines. $\mathrm{K}^{+} \mathrm{K} 14^{+}$basal-like cells (yellow arrows) are detected in most of the metastatic tumors regardless of DDR1 genotype. $(D, E)$ Data are shown as mean \pm SD. $n=3$. Unpaired Student's $t$ test. $(F, G) \mathrm{K} 8^{-} \mathrm{K} 14^{+}$basal cells (red arrows) significantly increased in DDR $1^{-/-}$small (length $<75 \mu \mathrm{m}$ ) metastatic tumors. $n=8$ 10. (*) $P<0.01 ; \quad(* *) \quad P<0.05$, one-way ANOVA and unpaired Student's $t$-test.

more CD90 ${ }^{+} \mathrm{CD} 24^{+}$cells (Fig. 5A,B). To understand the influence on epithelial differentiation by DDR1 deletion, we collected $\mathrm{CD} 90^{+} \mathrm{CD} 24^{+}$cells from both PyMT/DDR $1^{+/+}$ and PyMT/DDR $1^{-/-}$primary tumors by flow cytometry. We then transplanted $2000 \mathrm{CD}^{\circ} 0^{+} \mathrm{CD} 24^{+}$cells into the mammary glands of wild-type recipient mice. We observed sections of one grafted tumor from PyMT/ DDR $1^{+/+} \mathrm{CD} 90^{+} \mathrm{CD} 24^{+}$cells and two grafted tumors from PyMT/DDR1 ${ }^{-/-}$CD90 ${ }^{+} \mathrm{CD} 24^{+}$cells. The grafted tumors from PyMT/DDR $1^{+/+}$mice had a more luminal morphology with large epithelial clusters (Fig. 5C). In contrast, one grafted mammary tumor from PyMT/ DDR $1^{-1-}$ cells was less differentiated, and its size was larger (Fig. 5C). The other grafted tumor from PyMT/ $\mathrm{DDR}^{-/-}$cells grew huge once but shrank later and had areas of hemorrhagic necrosis (Fig. 5C). These PyMT/ DDR $1^{-/-} \mathrm{CD} 90^{+} \mathrm{CD} 24^{+}$cell-derived tumors displayed decreased expression of E-cadherin and increased vimentin ${ }^{+}$ cells and also had increased numbers of $\mathrm{K} 14^{+}$basal cells and $\mathrm{K} 88^{+} \mathrm{K} 14^{+}$basal-like cells near the necrotic areas (Fig. $5 \mathrm{D}-\mathrm{F})$. Tumor size correlated with increased $\mathrm{K} 14^{+}$basal cells in DDR $1^{-/-}$epithelial areas. These results indicate that, after transplantation with $\mathrm{CD} 90^{+} \mathrm{CD} 24^{+}$cells from primary tumors, the phenotype of the transplanted tumors resembled that of the primary tumor from which they were derived and suggest that DDR1 deletion in $\mathrm{CD}{ }^{+} \mathrm{CD} 24^{+}$cells induces basal differentiation and that the resulting increase in $\mathrm{K} 14^{+}$basal cells in the $\mathrm{DDR} 1^{-/-}$ epithelium promotes tumor growth.

\section{DDR1 expression predicts prognosis in breast cancer}

DDR1 is overexpressed in some breast, lung, ovarian, brain, and esophageal cancers and leukemia (Johnson et al. 1993; Zerlin et al. 1993; Laval et al. 1994; Alves et al. 1995; Barker et al. 1995; Perez et al. 1996; Ford et al. 2007), implicating DDR1 as a candidate oncogene. In breast cancer cell lines, DDR1 expression was higher in luminal-type than in basal-type human cell lines by microarray analysis (Supplemental Fig. S2C; Neve et al. 2006). When we stained the luminal-type (MCF7, T47D, SKBR3, and BT474) and basal-type (MDA-MB231 and HS578T) cell lines for DDR1 and E-cadherin by immunofluorescence, we observed staining on luminal-type cells (except in BT474) but not on basal-type cells (Fig. 6A,B). Cultured MMTV-PyMT mouse luminal B-type tumor cells that expressed E-cadherin also expressed DDR1 (Fig. 6C).

We next analyzed clinical data from breast cancer patients (Chin et al. 2006) and found that DDR1 expression was lower in basal-type than in luminal-type tumors (Fig. 6D). The relapse-free survival rate was lower in the patient group of low DDR1 expression by a Kaplan-Meier plot (Fig. 6E; Gyorffy et al. 2010; Szasz et al. 2016). These 
A

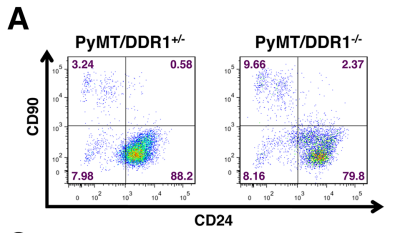

C

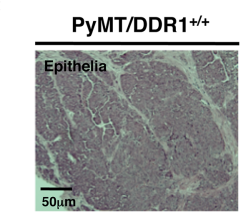

$\underset{\left(\mathrm{mm}^{3}\right)}{\operatorname{Tumor} \text { size }} \quad 94$

D PYMT/DDR1 $1^{1++}$

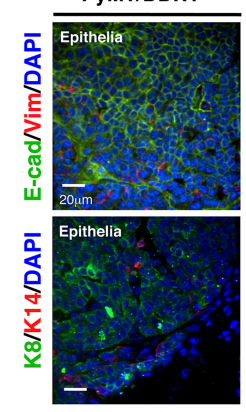

E

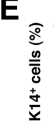
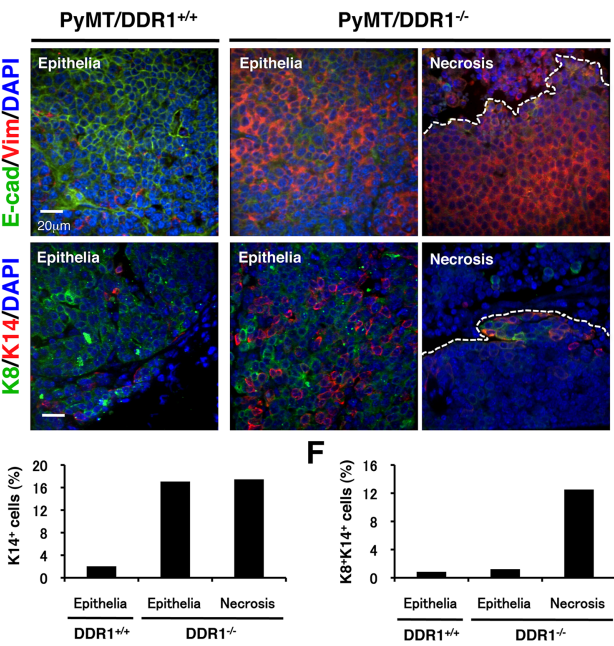

$\mathbf{F}$

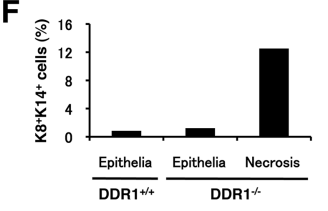

B

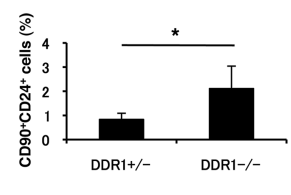

PyMT/DDR1 $\%$

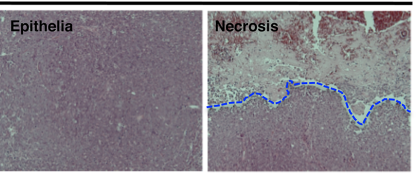

$(2254 \rightarrow) 65$

Figure 5. $\mathrm{CD} 90^{+} \mathrm{CD} 24^{+}$cells from PyMT/DDR $1^{-/-}$tumors transplanted into wild-type mice yield high-grade tumors resembling the PyMT/DDR $1^{-/-}$primary tumors. $(A, B)$ FACS analysis from $\mathrm{DDR}^{+/-}$and DDR $1^{-/-}$mammary tumor cells using antiCD90 and anti-CD24 antibodies. DDR1 ${ }^{-/-}$mammary tumor cells have more $\mathrm{CD} 90^{+} \mathrm{CD} 24^{+}$cancer cells than control tumors. Data are shown as mean \pm SD. $n=5-6 .\left(^{*}\right) P<0.02$, unpaired Student's $t$-test. $(C)$ Two-thousand $\mathrm{CD} 90^{+} \mathrm{CD} 24^{+}$cancer cells from PyMT/DDR $1^{+/+}$and PyMT/DDR $1^{-/-}$tumors were transplanted into mammary glands. We observed sections of one grafted tumor from PyMT/DDR $1^{+/+}$cells and two grafted tumors from PyMT/ $\mathrm{DDR}^{-/-}$cells. Mammary tumors from PyMT/DDR $1^{+/+}$cells showed large epithelial clusters by H\&E staining, whereas the mammary tumors from PyMT/DDR $1^{-/-}$cells showed noncluster structures and hemorrhagic necrosis. The blue dots represent a border between an epithelium and a necrotic field. Tumor size (in square micrometers) is indicated in each tumor when the tumors were obtained at $8 \mathrm{wk}$ after transplantation. The largest tumor size is also indicated before the necrotic tumor from PyMT/ DDR $1^{-/-}$cells shrank. (D) Immunofluorescence of $\mathrm{CD} 90^{+} \mathrm{CD} 24^{+}$ cell-derived mammary tumor tissues was conducted by using anti-E-cadherin (green) and anti-vimentin (red) antibodies in the top panel and anti-K8 (green) and anti-K14 (red) antibodies in the bottom panel. (Blue) DAPI-stained nuclei. The dots represent a border between an epithelium and a necrotic field. The mammary tumor from PyMT/DDR1 ${ }^{-1-} \mathrm{CD} 90^{+} \mathrm{CD} 24^{+}$cells shows decreased expression of E-cadherin, increased vimentin ${ }^{+}$cells (top panel), and increased $\mathrm{K} 14^{+}$basal cells (bottom panel). $(E, F)$ The ratio of $\mathrm{K} 14^{+}$basal cells $\left(\mathrm{K} 8^{-} \mathrm{K} 14^{+}\right.$and $\mathrm{K} 8{ }^{+} \mathrm{K} 14^{+}$cells) increased in DDR $1^{-1-}$ epithelial areas (shown in $E$ ). Increased $\mathrm{K}^{4} 4^{+}(E)$ and $\mathrm{K} 8^{+} \mathrm{K} 14^{+}(F)$ cells were seen near the necrotic field.

data suggest that DDR1 expression is prognostic of survival in breast cancer patients.

\section{Discussion}

In the present study, we discovered that luminal cells, but not basal/myoepithelial cells, express DDR 1 and that after DDR1 deletion, luminal-type MMTV-PyMT mammary tumors exhibit basal-type characteristics, grow faster, and have enhanced lung metastasis. The mechanism underlying these results may derive from a reduced ability of luminal cells to interact with collagen, leading to an enrichment of the basal cell population, basal differentiation of DDR $1^{-/-} \mathrm{CD} 90^{+} \mathrm{CD} 24^{+}$cells with primary tumor growth promoted by basal cells, and the enhanced tumor necrosis/hypoxia seen in DDR1 $1^{-/}$tumors, which in turn increases the number of $\mathrm{K}^{+} 4^{+}$basal cells, including $\mathrm{K} 8^{+} \mathrm{K} 14^{+}$cells (Fig. 7). Our data suggest that DDR 1 thwarts the development of poor-prognosis tumors. Thus, elimination of DDR1 may result in a more aggressive basal-type breast cancer. In keeping with these results, DDR 1 expression is lower in basal-type than in luminal-type tumors. Since the basal phenotype promotes the invasion/migration activity of mammary tumor cells (Hendrix et al. 1997; McInroy and Maatta 2007; Cheung et al. 2013; Corsa et al. 2016), this provides a second mechanism by which loss of DDR1 acts. Correlating with the DDR1-deficient mammary tumor model, we found that basal/myoepithelial cells increased in adult DDR1 $1^{-/}$mammary glands and facilitated mammary branching in vitro. This may be a mechanism underlying the mammary hyperbranching in adult mammary glands by DDR 1 ablation, and this effect may reflect breast tumor progression promoted by DDR 1 ablation. On the other hand, DDR 1 deletion decreased branching in mammary cells and tumor organoids in vitro and reduced mammary branches and ductal lengths in mammary development in vivo and luminal tumor cluster size in PyMT tumors (Table 1). These findings can be explained by impaired functions in collective cell migration and a collagen receptor by loss of DDR1.

Why does DDR1 deletion promote necrosis in luminal tumor epithelial cell regions? It is generally believed that central necrosis is caused by a shortage of the local blood supply (hypoxia) due to rapid tumor growth (Brown 2007). Since DDR $1^{-/-}$mammary tumors grew more rapidly, with an increase in fibrillar collagens that comprised a stiffer ECM, this allowed tumor necrosis to occur more frequently. Necrosis accretion in turn may increase numbers of $\mathrm{K}^{+} 4^{+}$basal cells and promote lung metastasis. These observations may explain the relationship between tumor necrosis and tumor aggressiveness.

The basal markers such as vimentin, K14, and DDR2 promote tumor cell invasion and correlate with poor prognosis (Hendrix et al. 1997; Thomas et al. 1999; Abd ElRehim et al. 2004; McInroy and Maatta 2007; Karantza 2011; Valiathan et al. 2012; Cheung et al. 2013; Ren et al. 2013; Zhang et al. 2013; Leitinger 2014; Corsa et al. 2016; Zelenko et al. 2017). Since DDR1 $1^{-/-}$tumors 
A

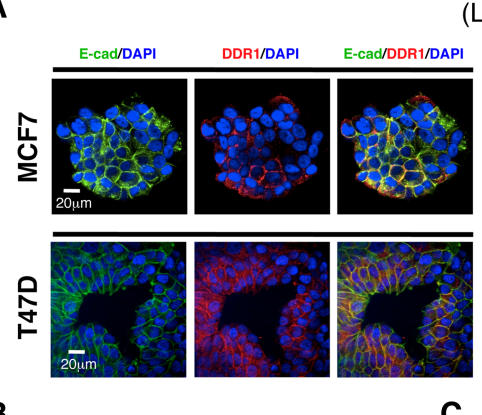

B

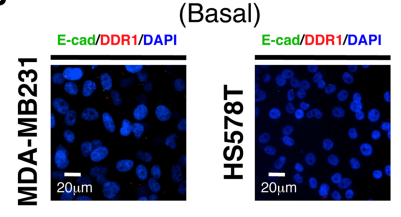

D

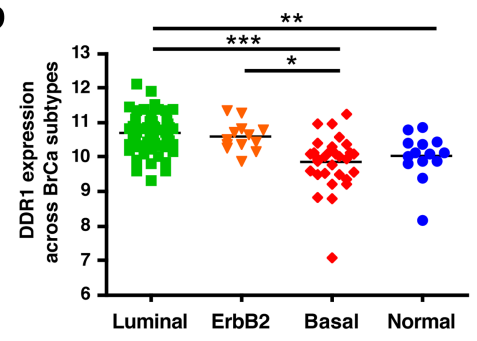

C
(Luminal)
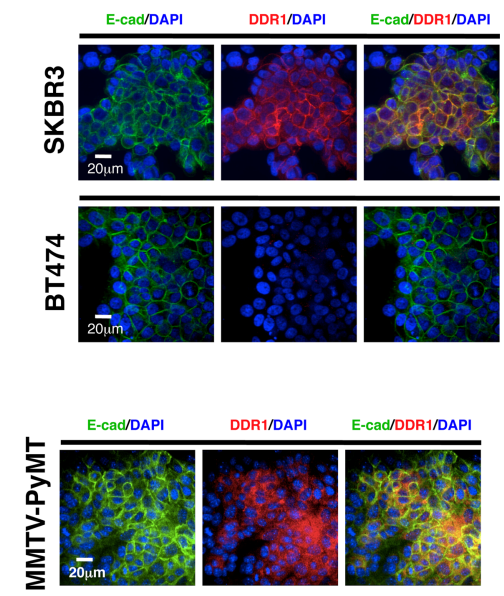

E

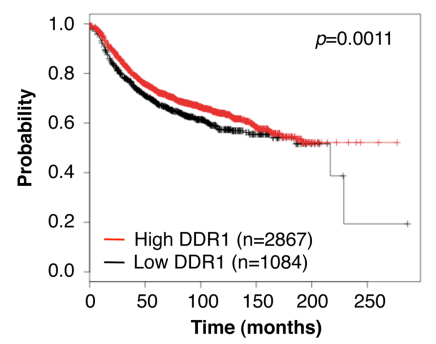

Figure 6. DDR1 expression predicts prognosis in breast cancer. $(A, B)$ Immunofluorescence of luminal-type (MCF7, T47D, SKBR3, and BT474) and basal-type (MDA-MB231 and HS578T) breast cancer cell lines was conducted by using anti-DDR1 (red) and anti-E-cadherin (green) antibodies. (Blue) DAPIstained nuclei. DDR1 and E-cadherin were detected on luminal-type cells (except BT474) (A) but not on basal-type cells $(B) .(C)$ Immunofluorescence of MMTV-PyMT luminal-type tumor cells in two-dimensional (2D) culture was conducted by using anti-DDR1 (red) and anti-E-cadherin (green) antibodies. (Blue) DAPI-stained nuclei. DDR1 and E-cadherin were expressed on the cells. $(D)$ Clinical data of breast cancer patients. DDR1 expression was lower in basal type than in luminal type. $\left({ }^{*}\right) P<0.05$; $\left.{ }^{* *}\right) P<0.01$; $\left({ }^{* * *}\right) P<0.001$, Dunn's multiple comparison test. $(E)$ Kaplan-Meier analysis of relapse-free survival for breast cancer patients. Low DDR1 expression was associated with worse relapse-free survival (log rank test). had increased vimentin expression, $\mathrm{K} 14^{+}$cells, and $\mathrm{DDR}^{+}$cells, we suggest that DDR1 ablation from the spontaneous luminal-type breast cancer model may lead to more basal-type characteristics and enhance tumor cell invasion as a mechanism of the tumor progression. However, DDR1 ablation up-regulated DDR2 expression mainly on $\mathrm{K}^{+}$luminal cells and $\mathrm{K} 8^{+} \mathrm{K} 14^{+}$basal-like cells rather than on basal cells or stromal cells, although previous reports indicated that DDR2 on basal cells or cancerassociated fibroblasts regulates tumor cell invasion (Zhang et al. 2013; Corsa et al. 2016). It has been reported that DDR1 switches to DDR2 expression by TGF $\beta$-exposed or SLUG transfected epithelial-to-mesenchymal transition (EMT) (Maeyama et al. 2008; Zhang et al. 2013). Interestingly, ECM stiffness can also regulate DDR2 to promote tumor cell invasion through an EMT and is well known to contribute to tumor hypoxia (Jain et al. 2014; Kim et al. 2017). Hypoxia dramatically increases phosphorylation of DDR2 in breast cancer cell lines, and DDR2 is involved in hypoxia-induced breast cancer cell invasion and EMT (Ren et al. 2014). Moreover, a $\mathrm{DDR} 1^{\mathrm{Low}} / \mathrm{DDR} 2^{\text {High }}$ protein profile is associated with triple-negative breast cancer and worse prognosis (Toy et al. 2015). More study is necessary to understand the mechanisms of the alteration from DDR1 to DDR2 on luminal cells and basal cells and determine whether the tumor cells can acquire invasive ability by up-regulation of basal markers, including DDR2.

Our data add to the concept that the effects of DDR 1 are complex. In mammary development, its loss inhibits mammary development early in puberty but increases epithelial branching later. Similarly, while our results found that knockout of DDR1 increased tumor progression in MMTV-PyMT tumors, knockdown of DDR1 decreased viability of luminal-type breast cancer cell lines (Marcotte et al. 2012), and interference with DDR1 function in a metastatic luminal-type breast cancer cell line decreased its ability to colonize lung tissue (Hidalgo-Carcedo et al. 2011). Those results suggest that DDR1 may behave as an oncogene in some circumstances and as an anti-oncogene in others.

How could such diverse effects arise? Since DDR1 knockdown in luminal cells impairs collective cell migration, cell adhesion, and contractility, this could reduce tumor growth (Hidalgo-Carcedo et al. 2011). In addition, induction of DDR1 expression inhibits migration of a DDR1-deficient basal-type breast cancer cell line (Hansen et al. 2006), which may be caused by enhanced cell adhesion through DDR1 induction. Therefore, the results with cell lines and/or in vitro experiments may be based on DDR 1 functions in collective cell migration and cell adhesion, which is different from possible effects of enhanced necrosis and increased $\mathrm{K} 14^{+}$basal cells and more basaltype characteristics by DDR1 deletion in our DDR1-deleted spontaneous model of luminal B-type breast cancer. In support of this hypothesis, our in vitro studies demonstrated that the tumor organoids derived from our PyMT/DDR $1^{-1-}$ tumors showed decreased branching. In our study, we did not observe an increase in carcinogenesis rates of DDR $1^{-/-}$mice compared with DDR $1^{+/+}$mice, as described in a previous report (Vogel et al. 2001), suggesting that DDR1 is not a tumor suppressor gene.

Activation and proliferation of $\mathrm{K} 14^{+}$basal cells and their invasive activity are important for tumor growth 


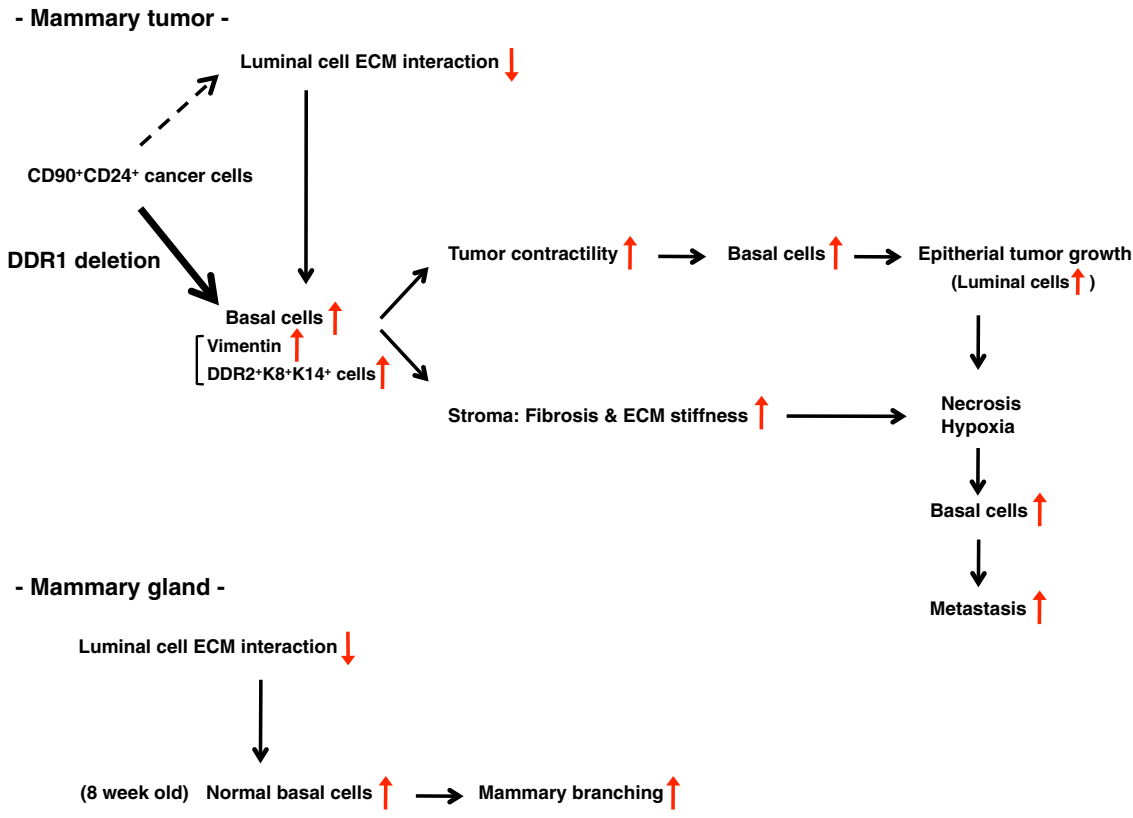

Figure 7. A model of tumor progression by DDR1 deletion. Our data suggest that DDR1 deletion induces reduced luminal cell-ECM interaction and basal differentiation of $\mathrm{CD} 90^{+} \mathrm{CD} 24^{+}$cells, and then increased $\mathrm{K}_{14}{ }^{+}$basal cells promote tumor contractility and fibrosis/ECM stiffness, leading to primary tumor growth. Rapid tumor growth leads to necrosis accretion, necrosis/hypoxia increases basal cells, and increased basal cells cause metastatic progression. $\mathrm{K}^{+} \mathrm{K} 14^{+}$basal-like cells may acquire invasive activity by up-regulation of DDR2. In mammary glands, reduced luminal cell-ECM interaction increases basal cells at 8 wk of age, which may promote mammary development. and metastasis. Our DDR1-deleted spontaneous breast cancer model showed both enhanced tumor necrosis/hypoxia and an increase in these cells with a more basal phenotype that may promote invasion of tumor cells. Thus, our research provides new insights into the complicated DDR1 roles in breast cancer that will contribute importantly to the understanding of cancer mechanisms in the future.

\section{Materials and methods}

\section{Mouse models}

All animal protocols were reviewed and approved by the University of California at San Francisco (UCSF) Institutional Animal Care and Use Committee. Mice were maintained under specific pathogen-free conditions in the UCSF Barrier Facility. DDR $1^{-/-}$ mice on a $129 / \mathrm{Sv}$ background were kindly provided by the late Wolfgang F. Vogel, University of Toronto (Vogel et al. 2001). $\mathrm{DDR}^{-1-}$ mice were then backcrossed to the FVB/n background for at least six generations.

For development studies, mammary glands were harvested from $\mathrm{DDR} 1^{-1-}$ mice on mixed $129 / \mathrm{Sv}$ and $\mathrm{FVB} / \mathrm{n}$ backgrounds and stained with carmine alum (Sigma). These mice were crossed with K14/GFP transgenic mice (CD1 background) in which GFP expression was controlled by a K14 promoter-driven transgene cassette (Hirakawa et al. 2005). For cancer studies, the DDR $1^{-/-}$ mice on the FVB/n background were crossed with MMTVPyMT mice on the FVB/n background. Tumor volumes (in square millimeters) were calculated using the formula $V=0.52 \times W^{2} \times L$, where $W$ is width (in millimeters) and $L$ is length (in millimeters).

$q P C R$

Total RNA was isolated from mouse mammary tumors using a Qiagen minikit. cDNA was synthesized using the SuperScript III RT first strand kit (Invitrogen). qPCR was performed using SYBR Green (Applied Biosystems) in an Eppendorf Mastercycler Realplex machine. Ct values were normalized to actin, and rela- tive expression was calculated using the $2^{\Delta \Delta \mathrm{Ct}}$ method (Slorach et al. 2011). The forward and reverse primer sequences for mouse DDR 1 were $5^{\prime}$-TCCATAGACCAGAGGGATC-3' and 5'-CAG GGCATAGCGGCACTTGG-3'.

\section{Flow cytometry analysis and cell sorting}

Mammary glands from DDR $1^{-/-}, \mathrm{K} 14 / \mathrm{DDR} 1^{-/-}$, and littermate control mice or mammary tumors from PyMT/DDR1 mice were digested with collagenase (Fata et al. 2007; Ewald et al. 2008). Organoids were collected by brief centrifugation and digested with trypsin to dissociate into single cells. Cultured adherent cells were trypsinized for single-cell suspensions. The cells were stained with antibodies against CD49f, CD24, and CD90.1 and lineage markers (CD45, CD31, and Ter119) (eBioscience), as described previously (Stingl et al. 2006; Malanchi et al. 2012). Cell sorting was performed on a FACS Aria II (Becton Dickinson) and analyzed using FlowJo (TreeStar) or FACSDiva (BD Biosciences) software.

\section{Traction force microscopy}

Primary murine mammary luminal and basal epithelial cells were sorted as described above and seeded overnight on collagen I-coated polyacrylamide gels with embedded 500-nm fluorescent red beads. Images of cells and beads were taken at $20 \times$ magnification before adding $2 \%$ SDS to lyse the cells. A second picture of the beads was taken after lysis and aligned with the first image using the ImageJ (http://rsb.info.nih.gov/ij) registration plug-in Linear Stack Alignment with SIFT. To assess bead movement, a particle image velocimetry (PIV) program was implemented in ImageJ as described previously (Tseng et al. 2012). The iterative scheme included a first pass at 32/64 (i.e., interrogation and search window size in pixels) followed by a second pass at 20/ 40, all at a correlation threshold of 0.60. For PIV post-processing, a normalized mean test (NMT) was performed as described (Tseng et al. 2012) with NMT noise of 0.2 and threshold of 2.0 as starting parameters. The traction force was calculated by the Fourier transform traction cytometry (FTTC) method with a Poisson ratio of 0.5 . The maximum traction stress generated was 
calculated by averaging the five largest traction vectors generated by each cell. The PIV and FTTC microscopy software for ImageJ was kindly made available by Qingzong Tseng (https://sites. google.com/site/qingzongtseng/tfm).

\section{$3 D$ organoid branching assay}

$\mathrm{K} 14^{-}$cells and $\mathrm{K} 14^{+}$cells with or without DDR1 were aggregated overnight on ultralow attachment plates (Corning) (Chou et al. 2013). The aggregated cells or organoids were embedded into growth factor-reduced Matrigel (BD Biosciences) and grown in serum-free medium supplemented with insulin-transferrin (Invitrogen) and $2.5 \mathrm{nM}$ EGF (Invitrogen) or $2.5 \mathrm{nM}$ FGF2 (Sigma) as described previously (Chou et al. 2013).

\section{Immunostaining and histology}

Tissues were fixed in 4\% PFA overnight and paraffin-processed. We cut 5 - $\mu \mathrm{m}$ sections from paraffin-embedded blocks for H\&E staining and immunohistochemistry. Adherent cells cultured in two-well chamber slides were stained by immunocytochemistry.

The following antibodies were used for immunofluorescence at the indicated concentrations: DDR1 (1:50; Santa Cruz Biotechnology, sc-532), E-cadherin (1:100; BD Biosciences, 610181), K8 (1:50; Developmental Studies Hybridoma Bank, TROMA-I), K14 (1:5000 [Convance, PRB-155P] and 1:100 [Santa Cruz Biotechnology, sc-17104]), a-SMA Cy3 conjugate (1:250; Sigma, C6198), vimentin (1:200; Sigma, V5255), DDR2 (1:50; LifeSpan BioSciences, LS-C164363), phH3 (1:100; Cell Signaling, 9701), HIF1 a (1:50; Novus Biologicals, NB100-479), pMLC2 (1:100; Cell Signaling Technology, 3671), goat anti-mouse IgM $\mu$ chain Cy3 conjugate (1:200; Jackson ImmunoResearch, 115-166-075), and Alexa 488 anti-rat, Alexa 488 anti-rabbit, Alexa 488 anti-mouse, Alexa 568 anti-rabbit, and Alexa 647 anti-goat secondary antibodies (1:500; Molecular Probes, A11006, A24922, A24920, A21069, and A21447). Nuclei were stained with DAPI (Vector Laboratories, H-1200). Confocal or fluorescence microscopy was performed on a Nikon C1si confocal microscope or a Keyence BZX700 fluorescence microscope.

\section{Picrosirius red quantification}

Picrosirius red staining was performed as described previously (Levental et al. 2009; Egeblad et al. 2010). Images were taken using polarized light such that only the birefringent collagen signal was visible. The amount of collagen was quantified as the percent area of the image with a positive signal using ImageJ. The threshold pixel value to determine a positive signal was held constant for each image analyzed.

\section{AFM measurements}

Tumor samples were frozen in OCT and cut into $30-\mu \mathrm{m}$ sections. Each section was thawed in room temperature PBS and maintained in $0.5 \%$ BSA with protease inhibitor (Sigma, p8340) in PBS supplemented with $20 \mu \mathrm{g} / \mathrm{mL}$ propidium iodide (Sigma, P4170) for no more than 90 min after thawing.

AFM measurements were performed as described previously (Lopez et al. 2011). All AFM indentations were performed using an MFP3D-BIO inverted optical atomic force microscope (Asylum Research) mounted on a Nikon TE2000-U inverted fluorescent microscope. We used a silicon nitride cantilever with an approximate spring constant of $0.06 \mathrm{~N} \mathrm{~m}^{-1}$ with a $5-\mu \mathrm{m}$ spherical borosilicate glass tip (Novascan Tech). The exact cantilever spring constant was determined using its thermal oscillation pri- or to each experiment. Samples were indented at a loading rate of $2 \mu \mathrm{m} / \mathrm{sec}$ until a maximum force of $1 \mathrm{nN}$ was achieved. Five $400-$ $\mu \mathrm{m} \times 40-\mu \mathrm{m}$ indentation maps were typically obtained on each tissue section in ECM-rich regions as determined through picrosirius red staining of serial tissue sections. The elastic modulus of the tissue was determined through fitting to the Hertz model using a Poisson's ratio of 0.5 , which assumes the tissue samples are incompressible.

\section{Western blot}

Homogenized tumor tissue or cells were lysed in 2\% SDS containing protease inhibitor cocktail (Sigma, p8340) and phosphatase inhibitor (GenDEPOT, P3200). Equal amounts of protein per sample were subjected to SDS-PAGE and transferred to a PVDF membrane. The membranes were blocked in $5 \%$ skim milk in TBST (TBS containing $0.1 \%$ Tween 20 ) for $30 \mathrm{~min}$. Primary antibodies were incubated overnight at $4^{\circ} \mathrm{C}$ in $3 \%$ BSA in TBST. Membranes were incubated with horseradish peroxidase (HRP)-conjugated secondary antibodies diluted in 5\% milk and TBST for $1 \mathrm{~h}$ at room temperature. Bands were visualized using Pierce ECL Plus Western blotting substrate (ThermoFisher 32132). Protein expression was quantified by measuring the pixel intensity of each band using ImageJ. pFAK/FAK represents the ratio of the pFAK signal to the total FAK signal of each sample.

Antibodies used were as follows: rabbit anti-DDR1 (Cell Signaling Technology, 5583), mouse anti-FAK (BD Biosciences, 610088), rabbit anti-pFAK ${ }^{\mathrm{Y} 397}$ (Cell Signaling Technology, 8556), and mouse anti- $\beta$-actin (Sigma, A5441).

\section{Lung metastasis analysis}

To determine lung metastatic tumor volume and frequency, lung tissue blocks were sectioned into 5 - $\mu \mathrm{m}$ sections and stained by H\&E. For each mouse analyzed, one section was scored for size and number of metastases per lobe (Littlepage et al. 2010, 2012). Tumor volumes (in square micrometers) were calculated using the formula $V=0.52 \times W^{2} \times L$, where $W$ is width (in micrometers) and $L$ is length (in micrometers).

\section{Transplantation}

We injected $2 \times 10^{3}$ cells $\left(\mathrm{CD} 90^{+} \mathrm{CD} 24^{+} \mathrm{CSC}\right.$ from PyMT/ DDR $1^{+/+}$or PyMT/DDR $1^{-/-}$tumors) in a $10-\mu \mathrm{L}$ volume of $1: 1$ (v/v) Matrigel:DMEM/F12 medium into the mammary glands of $\mathrm{FVB} / \mathrm{n}$ mice using a Hamilton syringe. Tumors were harvested 8 wk after transplantation.

\section{Cell culture}

MCF7, T47D, SKBR3, BT474, MDA-MB231, and HS578T cells were obtained from American Type Culture Collection, Lawrence Berkeley Laboratory, or the UCSF Cell Culture Facility and grown in DME H-21 medium supplemented with $10 \%$ FBS and $1 \mu \mathrm{g} / \mathrm{mL}$ insulin. Organoids from MMTV-PyMT mammary tumors (see "Flow Cytometry Analysis and Cell Sorting") were cultured in ACL4 + 5\% FBS medium (Brower et al. 1986) in a 3\% $\mathrm{O}_{2}$ incubator.

\section{Computational analysis}

We compared DDR 1 expression levels in 25 luminal and 26 basal (A + B) cell lines and also in 61 luminal-type, 13 HER2-type, and 30 basal-type human breast tumors and 14 normal human breast tissues using the published microarray data sets (Chin et al. 2006; Neve et al. 2006). Breast cancer patients $(n=3951)$ were separated 
by high $(n=2867)$ versus low $(n=1084)$ DDR1 expression and analyzed for relapse-free survival by a Kaplan-Meier plot (Gyorffy et al. 2010; Szasz et al. 2016).

\section{Statistical analysis}

Statistical analysis was conducted using Prism 4 software (Graph Pad Software, Inc.). Kaplan-Meier survival curves were analyzed by $\log$ rank tests to determine the significance of observed differences between the curves. All tests used and $P$-values are specified in the figure legends. $P<0.05$ was considered significant.

\section{Acknowledgments}

We dedicate this study to the memory of Wolfgang Vogel, who made the DDR1 knockout and would have collaborated on the study except for his untimely death. We thank Y. Yu, M. Matsuoka, J. Yasunaga, and K. Shimura for technical assistance, and $M$. Inoue for helpful suggestions. This study was supported by funds from the National Cancer Institute (R01 CA057621 to Z.W., R01 CA192914 to V.M.W., K22 CA190511 to D.A.L., and K99/R00 CA181490 to K.K.), a Developmental Project award from the University of California at San Francisco Helen Diller Family Comprehensive Cancer Center Breast Oncology Program (to Z.W.), funds from the Department of Defense Breast Cancer Research Program (BC122990 to V.M.W.), a University of California at San Francisco Predoctoral Fellowship in Cancer Research (to A.P.D.), and funds from the American Cancer Society, the Indiana Clinical and Translational Sciences Institute, and the Mary Kay Foundation (to L.E.L.).

\section{References}

Abd El-Rehim DM, Pinder SE, Paish CE, Bell J, Blamey RW, Robertson JF, Nicholson RI, Ellis IO. 2004. Expression of luminal and basal cytokeratins in human breast carcinoma. I Pathol 203: 661-671.

Alves F, Vogel W, Mossie K, Millauer B, Hofler H, Ullrich A. 1995. Distinct structural characteristics of discoidin I subfamily receptor tyrosine kinases and complementary expression in human cancer. Oncogene 10: 609-618.

Barker KT, Martindale JE, Mitchell PJ, Kamalati T, Page MJ, Phippard DJ, Dale TC, Gusterson BA, Crompton MR. 1995. Expression patterns of the novel receptor-like tyrosine kinase, DDR, in human breast tumours. Oncogene 10: 569-575.

Brower M, Carney DN, Oie HK, Gazdar AF, Minna JD. 1986. Growth of cell lines and clinical specimens of human nonsmall cell lung cancer in a serum-free defined medium. Cancer Res 46: 798-806.

Brown JM. 2007. Tumor hypoxia in cancer therapy. Methods Enzymol 435: 297-321.

Cheung KJ, Gabrielson E, Werb Z, Ewald AJ. 2013. Collective invasion in breast cancer requires a conserved basal epithelial program. Cell 155: 1639-1651.

Chin K, DeVries S, Fridlyand J, Spellman PT, Roydasgupta R, Kuo WL, Lapuk A, Neve RM, Qian Z, Ryder T, et al. 2006. Genomic and transcriptional aberrations linked to breast cancer pathophysiologies. Cancer Cell 10: 529-541.

Chou J, Lin JH, Brenot A, Kim JW, Provot S, Werb Z. 2013. GATA3 suppresses metastasis and modulates the tumour microenvironment by regulating microRNA-29b expression. Nat Cell Biol 15: 201-213.
Corsa CA, Brenot A, Grither WR, Van Hove S, Loza AJ, Zhang K, Ponik SM, Liu Y, DeNardo DG, Eliceiri KW, et al. 2016. The action of discoidin domain receptor 2 in basal tumor cells and stromal cancer-associated fibroblasts is critical for breast cancer metastasis. Cell Rep 15: 2510-2523.

Egeblad M, Nakasone ES, Werb Z. 2010. Tumors as organs: complex tissues that interface with the entire organism. Dev Cell 18: 884-901.

Eswaramoorthy R, Wang CK, Chen WC, Tang MJ, Ho ML, Hwang CC, Wang HM, Wang CZ. 2010. DDR1 regulates the stabilization of cell surface E-cadherin and E-cadherin-mediated cell aggregation. J Cell Physiol 224: 387-397.

Ewald AJ, Brenot A, Duong M, Chan BS, Werb Z. 2008. Collective epithelial migration and cell rearrangements drive mammary branching morphogenesis. Dev Cell 14: 570-581.

Fata JE, Mori H, Ewald AJ, Zhang H, Yao E, Werb Z, Bissell MJ. 2007. The MAPK(ERK-1,2) pathway integrates distinct and antagonistic signals from TGFa and FGF7 in morphogenesis of mouse mammary epithelium. Dev Biol 306: 193-207.

Ferri N, Carragher NO, Raines EW. 2004. Role of discoidin domain receptors 1 and 2 in human smooth muscle cell-mediated collagen remodeling: potential implications in atherosclerosis and lymphangioleiomyomatosis. Am I Pathol 164: 1575-1585.

Ford CE, Lau SK, Zhu CQ, Andersson T, Tsao MS, Vogel WF. 2007. Expression and mutation analysis of the discoidin domain receptors 1 and 2 in non-small cell lung carcinoma. Br J Cancer 96: 808-814.

Fulford LG, Easton DF, Reis-Filho JS, Sofronis A, Gillett CE, Lakhani SR, Hanby A. 2006. Specific morphological features predictive for the basal phenotype in grade 3 invasive ductal carcinoma of breast. Histopathology 49: 22-34.

Gao H, Chakraborty G, Zhang Z, Akalay I, Gadiya M, Gao Y, Sinha S, Hu J, Jiang C, Akram M, et al. 2016. Multi-organ site metastatic reactivation mediated by non-canonical discoidin domain receptor 1 signaling. Cell 166: 47-62.

Gilchrist KW, Gray R, Fowble B, Tormey DC, Taylor SG IV. 1993. Tumor necrosis is a prognostic predictor for early recurrence and death in lymph node-positive breast cancer: a 10-year follow-up study of 728 Eastern Cooperative Oncology Group patients. J Clin Oncol 11: 1929-1935.

Gyorffy B, Lanczky A, Eklund AC, Denkert C, Budczies J, Li Q, Szallasi Z. 2010. An online survival analysis tool to rapidly assess the effect of 22,277 genes on breast cancer prognosis using microarray data of 1,809 patients. Breast Cancer Res Treat 123: $725-731$.

Hansen C, Greengard P, Nairn AC, Andersson T, Vogel WF. 2006. Phosphorylation of DARPP-32 regulates breast cancer cell migration downstream of the receptor tyrosine kinase DDR1. Exp Cell Res 312: 4011-4018.

Hendrix MJ, Seftor EA, Seftor RE, Trevor KT. 1997. Experimental co-expression of vimentin and keratin intermediate filaments in human breast cancer cells results in phenotypic interconversion and increased invasive behavior. Am J Pathol 150: 483-495.

Hidalgo-Carcedo C, Hooper S, Chaudhry SI, Williamson P, Harrington K, Leitinger B, Sahai E. 2011. Collective cell migration requires suppression of actomyosin at cell-cell contacts mediated by DDR1 and the cell polarity regulators Par3 and Par6. Nat Cell Biol 13: 49-58.

Hirakawa S, Kodama S, Kunstfeld R, Kajiya K, Brown LF, Detmar M. 2005. VEGF-A induces tumor and sentinel lymph node lymphangiogenesis and promotes lymphatic metastasis. I Exp Med 201: 1089-1099. 
Hou G, Vogel W, Bendeck MP. 2001. The discoidin domain receptor tyrosine kinase DDR1 in arterial wound repair. J Clin Invest 107: 727-735.

Hou G, Vogel WF, Bendeck MP. 2002. Tyrosine kinase activity of discoidin domain receptor 1 is necessary for smooth muscle cell migration and matrix metalloproteinase expression. Circ Res 90: 1147-1149.

Huo Y, Yang M, Liu W, Yang J, Fu X, Liu D, Li J, Zhang J, Hua R, Sun Y. 2015. High expression of DDR1 is associated with the poor prognosis in Chinese patients with pancreatic ductal adenocarcinoma. J Exp Clin Cancer Res 34: 88.

Jain RK, Martin JD, Stylianopoulos T. 2014. The role of mechanical forces in tumor growth and therapy. Annu Rev Biomed Eng 16: 321-346.

Johnson JD, Edman JC, Rutter WJ. 1993. A receptor tyrosine kinase found in breast carcinoma cells has an extracellular discoidin I-like domain. Proc Natl Acad Sci 90: 5677-5681.

Karantza V. 2011. Keratins in health and cancer: more than mere epithelial cell markers. Oncogene 30: 127-138.

Kim D, You E, Jeong J, Ko P, Kim JW, Rhee S. 2017. DDR2 controls the epithelial-mesenchymal-transition-related gene expression via c-Myb acetylation upon matrix stiffening. Sci Rep 7: 6847.

Laval S, Butler R, Shelling AN, Hanby AM, Poulsom R, Ganesan TS. 1994. Isolation and characterization of an epithelial-specific receptor tyrosine kinase from an ovarian cancer cell line. Cell Growth Differ 5: 1173-1183.

Lee R, Eidman KE, Kren SM, Hostetter TH, Segal Y. 2004. Localization of discoidin domain receptors in rat kidney. Nephron Exp Nephrol 97: e62-e70.

Leight JL, Drain AP, Weaver VM. 2017. Extracellular matrix remodeling and stiffening modulate tumor phenotype and treatment response. Annu Rev Cancer Biol 1: 313-334.

Leitinger B. 2014. Discoidin domain receptor functions in physiological and pathological conditions. Int Rev Cell Mol Biol 310: 39-87.

Levental KR, Yu H, Kass L, Lakins JN, Egeblad M, Erler JT, Fong SF, Csiszar K, Giaccia A, Weninger W, et al. 2009. Matrix crosslinking forces tumor progression by enhancing integrin signaling. Cell 139: 891-906.

Lin EY, Jones JG, Li P, Zhu L, Whitney KD, Muller WJ, Pollard JW. 2003. Progression to malignancy in the polyoma middle $T$ oncoprotein mouse breast cancer model provides a reliable model for human diseases. Am I Pathol 163: 2113-2126.

Littlepage LE, Sternlicht MD, Rougier N, Phillips J, Gallo E, Yu Y, Williams K, Brenot A, Gordon JI, Werb Z. 2010. Matrix metalloproteinases contribute distinct roles in neuroendocrine prostate carcinogenesis, metastasis, and angiogenesis progression. Cancer Res 70: 2224-2234.

Littlepage LE, Adler AS, Kouros-Mehr H, Huang G, Chou J, Krig SR, Griffith OL, Korkola JE, Qu K, Lawson DA, et al. 2012. The transcription factor ZNF217 is a prognostic biomarker and therapeutic target during breast cancer progression. Cancer Discov 2: 638-651.

Lopez JI, Kang I, You WK, McDonald DM, Weaver VM. 2011. In situ force mapping of mammary gland transformation. Integr Biol 3: 910-921.

Maeyama M, Koga H, Selvendiran K, Yanagimoto C, Hanada S, Taniguchi E, Kawaguchi $T$, Harada $M$, Ueno $T$, Sata $M$. 2008. Switching in discoid domain receptor expressions in SLUG-induced epithelial-mesenchymal transition. Cancer 113: 2823-2831.

Malanchi I, Santamaria-Martinez A, Susanto E, Peng H, Lehr HA, Delaloye JF, Huelsken J. 2012. Interactions between cancer stem cells and their niche govern metastatic colonization. $\mathrm{Na}$ ture 481: 85-89.

Marcotte R, Brown KR, Suarez F, Sayad A, Karamboulas K, Krzyzanowski PM, Sircoulomb F, Medrano M, Fedyshyn Y, Koh JL, et al. 2012. Essential gene profiles in breast, pancreatic, and ovarian cancer cells. Cancer Discov 2: 172-189.

McInroy L, Maatta A. 2007. Down-regulation of vimentin expression inhibits carcinoma cell migration and adhesion. Biochem Biophys Res Commun 360: 109-114.

Neuhaus B, Buhren S, Bock B, Alves F, Vogel WF, Kiefer F. 2011. Migration inhibition of mammary epithelial cells by Syk is blocked in the presence of DDR1 receptors. Cell Mol Life Sci 68: 3757-3770.

Neve RM, Chin K, Fridlyand J, Yeh J, Baehner FL, Fevr T, Clark L, Bayani N, Coppe JP, Tong F, et al. 2006. A collection of breast cancer cell lines for the study of functionally distinct cancer subtypes. Cancer Cell 10: 515-527.

Northey JJ, Przybyla L, Weaver VM. 2017. Tissue force programs cell fate and tumor aggression. Cancer Discov 7: 1224-1237.

Perez JL, Jing SQ, Wong TW. 1996. Identification of two isoforms of the Cak receptor kinase that are coexpressed in breast tumor cell lines. Oncogene 12: 1469-1477.

Perou CM, Sorlie T, Eisen MB, van de Rijn M, Jeffrey SS, Rees CA, Pollack JR, Ross DT, Johnsen H, Akslen LA, et al. 2000. Molecular portraits of human breast tumours. Nature 406: 747-752.

Quan J, Yahata T, Adachi S, Yoshihara K, Tanaka K. 2011. Identification of receptor tyrosine kinase, discoidin domain receptor 1 (DDR 1), as a potential biomarker for serous ovarian cancer. Int J Mol Sci 12: 971-982.

Ram R, Lorente G, Nikolich K, Urfer R, Foehr E, Nagavarapu U. 2006. Discoidin domain receptor-1a (DDRla) promotes glioma cell invasion and adhesion in association with matrix metalloproteinase-2. J Neurooncol 76: 239-248.

Ren T, Zhang J, Liu X, Yao L. 2013. Increased expression of discoidin domain receptor 2 (DDR2): a novel independent prognostic marker of worse outcome in breast cancer patients. Med Oncol 30: 397.

Ren T, Zhang W, Liu X, Zhao H, Zhang J, Zhang J, Li X, Zhang Y, $\mathrm{Bu} X$, Shi M, et al. 2014. Discoidin domain receptor 2 (DDR2) promotes breast cancer cell metastasis and the mechanism implicates epithelial-mesenchymal transition programme under hypoxia. J Pathol 234: 526-537.

Roberts ME, Magowan L, Hall IP, Johnson SR. 2011. Discoidin domain receptor 1 regulates bronchial epithelial repair and matrix metalloproteinase production. Eur Respir $I$ 37: 1482-1493.

Shrivastava A, Radziejewski C, Campbell E, Kovac L, McGlynn M, Ryan TE, Davis S, Goldfarb MP, Glass DI, Lemke G, et al. 1997. An orphan receptor tyrosine kinase family whose members serve as nonintegrin collagen receptors. Mol Cell 1: 25-34.

Slorach EM, Chou J, Werb Z. 2011. Zeppo1 is a novel metastasis promoter that represses E-cadherin expression and regulates p120-catenin isoform expression and localization. Genes Dev 25: 471-484.

Sorlie T, Perou CM, Tibshirani R, Aas T, Geisler S, Johnsen H, Hastie T, Eisen MB, van de Rijn M, Jeffrey SS, et al. 2001. Gene expression patterns of breast carcinomas distinguish tumor subclasses with clinical implications. Proc Natl Acad Sci 98: 10869-10874.

Sorlie T, Tibshirani R, Parker J, Hastie T, Marron JS, Nobel A, Deng S, Johnsen H, Pesich R, Geisler S, et al. 2003. Repeated observation of breast tumor subtypes in independent gene expression data sets. Proc Natl Acad Sci 100: 8418-8423. 
Stingl J, Eirew P, Ricketson I, Shackleton M, Vaillant F, Choi D, Li HI, Eaves CJ. 2006. Purification and unique properties of mammary epithelial stem cells. Nature 439: 993-997.

Szasz AM, Lanczky A, Nagy A, Forster S, Hark K, Green JE, Boussioutas A, Busuttil R, Szabo A, Gyorffy B. 2016. Cross-validation of survival associated biomarkers in gastric cancer using transcriptomic data of 1,065 patients. Oncotarget 7: 4932249333.

Thomas PA, Kirschmann DA, Cerhan JR, Folberg R, Seftor EA, Sellers TA, Hendrix MJ. 1999. Association between keratin and vimentin expression, malignant phenotype, and survival in postmenopausal breast cancer patients. Clin Cancer Res 5: 2698-2703.

Toy KA, Valiathan RR, Nunez F, Kidwell KM, Gonzalez ME, Fridman R, Kleer CG. 2015. Tyrosine kinase discoidin domain receptors DDR1 and DDR2 are coordinately deregulated in triple-negative breast cancer. Breast Cancer Res Treat 150: 9-18.

Tseng Q, Duchemin-Pelletier E, Deshiere A, Balland M, Guillou H, Filhol O, Thery M. 2012. Spatial organization of the extracellular matrix regulates cell-cell junction positioning. Proc Natl Acad Sci 109: 1506-1511.

Valencia K, Ormazabal C, Zandueta C, Luis-Ravelo D, Anton I, Pajares MJ, Agorreta J, Montuenga LM, Martinez-Canarias S, Leitinger B, et al. 2012. Inhibition of collagen receptor discoidin domain receptor-1 (DDR1) reduces cell survival, homing, and colonization in lung cancer bone metastasis. Clin Cancer Res 18: 969-980.

Valiathan RR, Marco M, Leitinger B, Kleer CG, Fridman R. 2012. Discoidin domain receptor tyrosine kinases: new players in cancer progression. Cancer Metastasis Rev 31: 295-321. van de Rijn M, Perou CM, Tibshirani R, Haas P, Kallioniemi O, Kononen J, Torhorst J, Sauter G, Zuber M, Kochli OR, et al. 2002. Expression of cytokeratins 17 and 5 identifies a group of breast carcinomas with poor clinical outcome. Am I Pathol 161: 1991-1996.

Vogel W, Gish GD, Alves F, Pawson T. 1997. The discoidin domain receptor tyrosine kinases are activated by collagen. Mol Cell 1: 13-23.

Vogel WF, Aszodi A, Alves F, Pawson T. 2001. Discoidin domain receptor 1 tyrosine kinase has an essential role in mammary gland development. Mol Cell Biol 21: 2906-2917.

Xu H, Bihan D, Chang F, Huang PH, Farndale RW, Leitinger B. 2012. Discoidin domain receptors promote $\alpha 1 \beta 1$ - and $\alpha 2 \beta 1$ integrin mediated cell adhesion to collagen by enhancing integrin activation. PLoS One 7: e52209.

Yeh YC, Wu CC, Wang YK, Tang MJ. 2011. DDR1 triggers epithelial cell differentiation by promoting cell adhesion through stabilization of E-cadherin. Mol Biol Cell 22: 940-953.

Zelenko Z, Gallagher EJ, Tobin-Hess A, Belardi V, Rostoker R, Blank J, Dina Y, LeRoith D. 2017. Silencing vimentin expression decreases pulmonary metastases in a pre-diabetic mouse model of mammary tumor progression. Oncogene 36: 1394-1403.

Zerlin M, Julius MA, Goldfarb M. 1993. NEP: a novel receptorlike tyrosine kinase expressed in proliferating neuroepithelia. Oncogene 8: 2731-2739.

Zhang K, Corsa CA, Ponik SM, Prior JL, Piwnica-Worms D, Eliceiri KW, Keely PI, Longmore GD. 2013. The collagen receptor discoidin domain receptor 2 stabilizes SNAIL1 to facilitate breast cancer metastasis. Nat Cell Biol 15: 677-687. 


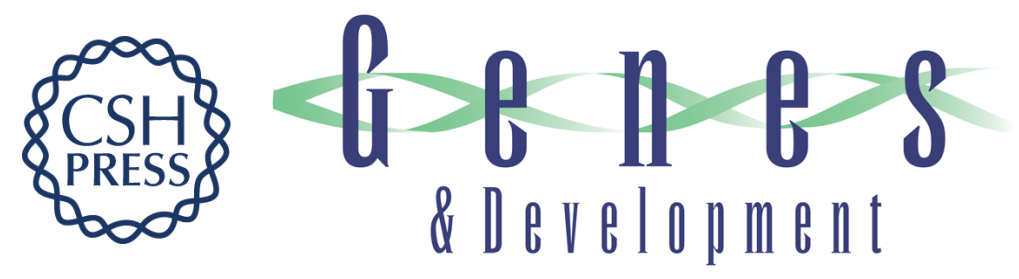

\section{Discoidin domain receptor 1 (DDR1) ablation promotes tissue fibrosis and hypoxia to induce aggressive basal-like breast cancers}

Ken Takai, Allison P. Drain, Devon A. Lawson, et al.

Genes Dev. 2018, 32: originally published online February 26, 2018

Access the most recent version at doi:10.1101/gad.301366.117

\section{Supplemental Material \\ http://genesdev.cshlp.org/content/suppl/2018/02/24/gad.301366.117.DC1}

References

This article cites 72 articles, 19 of which can be accessed free at: http://genesdev.cshlp.org/content/32/3-4/244.full.htmI\#ref-list-1

Creative This article is distributed exclusively by Cold Spring Harbor Laboratory Press for the first Commons License Email Alerting
Service six months after the full-issue publication date (see http://genesdev.cshlp.org/site/misc/terms.xhtml). After six months, it is available under a Creative Commons License (Attribution-NonCommercial 4.0 International), as described at http://creativecommons.org/licenses/by-nc/4.0/.

Receive free email alerts when new articles cite this article - sign up in the box at the top right corner of the article or click here.

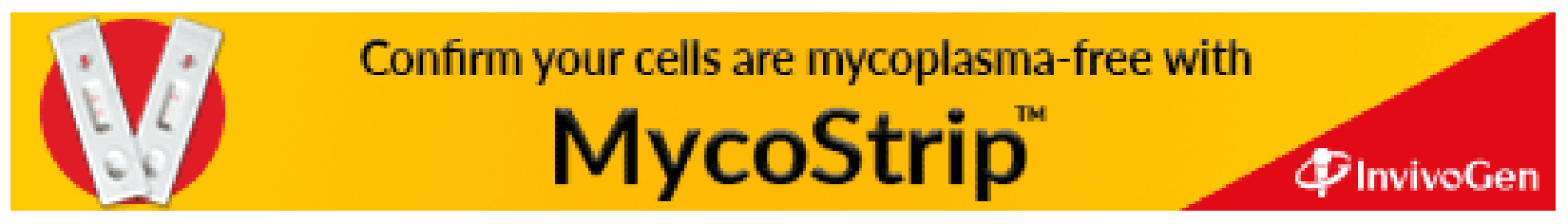

